Portland State University

PDXScholar

5-25-1995

\title{
Sustainable Development in the Third World: A New Paradigm?
}

Terry A. Gentry

Portland State University

Follow this and additional works at: https://pdxscholar.library.pdx.edu/open_access_etds

Part of the Political Science Commons

Let us know how access to this document benefits you.

Recommended Citation

Gentry, Terry A., "Sustainable Development in the Third World: A New Paradigm?" (1995). Dissertations and Theses. Paper 4905.

https://doi.org/10.15760/etd.6781

This Thesis is brought to you for free and open access. It has been accepted for inclusion in Dissertations and Theses by an authorized administrator of PDXScholar. Please contact us if we can make this document more accessible: pdxscholar@pdx.edu. 


\section{THESIS APPROVAL}

The abstract and thesis of Terry A. Gentry for the Master of Science in Political Science were presented May 25, 1995, and accepted by the thesis committee and the department.

COMMITTEE APPROVALS:

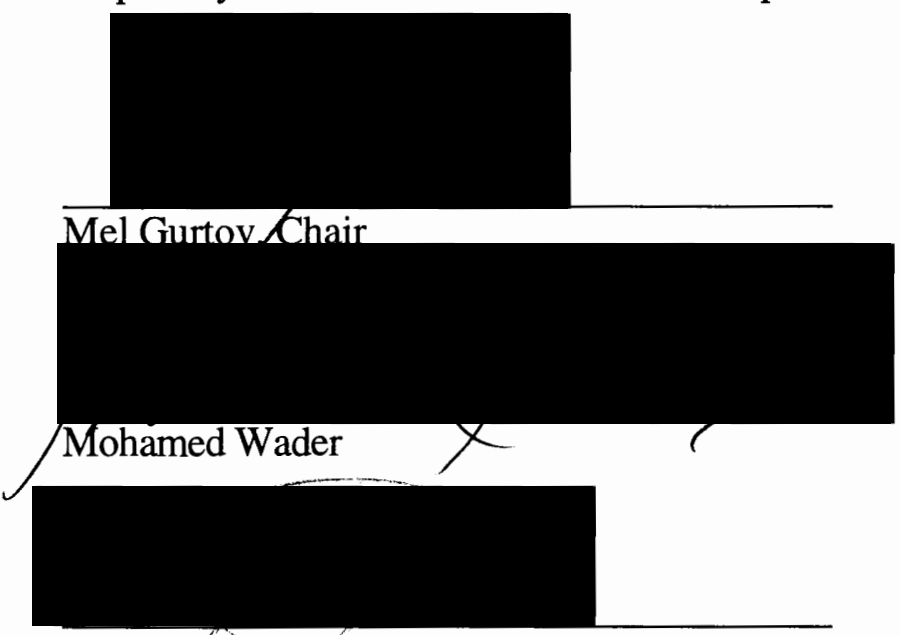

Richard Brinkmán

Representative of the Office of Graduate Studies

DEPARTMENT APPROVAL:

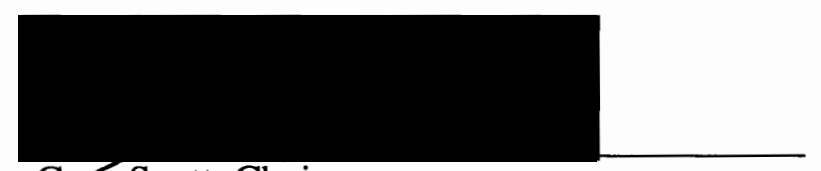

Gary Scott, Chair

Department of Political Science

$* * * * * * * * * * * * * * * * * * * * * * * * * * * * * * * * * * * * * * * * * * * * *$

ACCEPTED FOR PORTLAND STATE UNIVERSITY BY THE LIBRARY

by

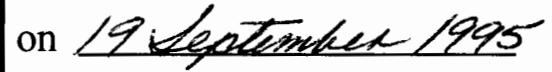




\begin{abstract}
An abstract of the thesis of Terry A. Gentry for the Master of Science in Political Science presented May 25, 1995.
\end{abstract}

Title: Sustainable Development in the Third World: A New Paradigm?

Over the past decade "Sustainable Development" (SD) has emerged as the latest development catchphrase. A wide range of nongovernmental as well as governmental organizations have embraced it as the new paradigm of development. A review of the literature that has sprung up around the concept of SD indicates, however, a lack of consistency in its interpretation. More important, while the all-encompassing nature of the concept gives it political strength, its current formulation by the mainstream of SD thinking contains significant weaknesses. These include an incomplete perception of the problems of poverty and environmental degradation, and confusion about the role of economic growth and about the concept of sustainability.

The purpose of this study was to identify common elements in a political economy of the environment, relating environmental change to the dynamics of ideology and policy, and at different levels of political complexity. The intention was to provide a structural analysis of the environment in which the development process illuminates environmental change at both a philosophical and material level. 
The problem in achieving SD was related to the overriding structures of the international economic system, which have arisen out of the exploitation of environmental resources, and which frequently operate as constraints on the achievement of long-term sustainable practices. Insufficient accounting of ecological aspects of economic growth and development has resulted from intellectual traditions, where solutions are formulated, point in different directions.

Conclusions are drawn that SD involves trade-offs between biological, economic and social systems and is found in the interactive zone between these systems. There are a number of international factors that may be necessary, but insufficient, conditions for SD on a national level, including peace, debt reduction, and more propitious terms of trade. There was seen dilemmas relating to $\mathrm{SD}$, including the role of growth as the unquestioned objective of economic policy. 
Sustainable Development in the Third World: A New Paradigm?

\author{
b y \\ Terry A. Gentry
}

A thesis submitted in partial fulfillment of the requirement for the degree of

\title{
MASTER OF SCIENCE \\ in \\ POLITICAL SCIENCE
}

Portland State University

1995 


\section{CHAPTER 1. INTRODUCTION}

In the last decade a central concept in the debate about environmental protection and development has been sustainable development (SD). The term SD has become something of a buzzword for politicians, scholars, practitioners and participants in development. The usually ill-defined language of SD has become endemic, appearing with as much frequency in World Bank publications as in the rhetoric of grass-roots movements. ${ }^{1}$ It appears to have gained the broad-based support that earlier development concepts such as "ecodevelopment" lacked, and is poised to become the dominant development paradigm.

But murmurs of disenchantment are also being heard. "What is SD?" is being asked with increasing frequency without, however, clear answers forthcoming. $S D$ is in real danger of becoming a cliché like appropriate technology -- a fashionable phrase that people pay homage to but which nobody clearly understands. As Mostafa Tolba has lamented, SD has become "an article of faith, a shibboleth; often used, but little explained."2

1 For example, World Bank, (1992). The Development Report, World Bank, Washington, D.C.; and Turner, B.L.; Clark, W.C., Kates, R.B., Richards, J.F., Mathews, J.T., and Meyer, W.B. (eds) (1990), The Earth as Transformed by Human Action, Cambridge University Press, Cambridge.

2 Tolba, Mostafa (1987). Sustainable Development: Constraints and Opportunities, Butterworths, London, p. 2. 


\section{Crisis in the Third World}

Crisis has become a commonplace motif of development writing. ${ }^{3}$ The perception of dramatic and unsolvable problems in the countries of the "South" is common to politicians, aid agencies, academic analysts, and the media. The 1984 drought in Sahelian Africa intensified this perception, leading to astonishing individual generosity of those people unkindly (but perhaps accurately) described as "the fat and happy in rich countries." 4 This indicates the disturbingly durable nature of the resulting picture of poverty: it seems possible for the Third World to be perceived as being locked in a permanent state of crisis of politics, economics and environmental degradation.

This view of crisis tends to favor "firefighting" approaches to development as against discussions of deeper ills, and the treatment of symptoms rather than causes. Thus Julius Nyerere commented in 1985: "Africa starvation is topical, but the relations between rich and poor countries which underlie Africa's vulnerability to natural disasters have been relegated to the

3 See for example, Ekins, Paul (1992). A New World Order: Grassroots Movements for Global Change, Routledge, New York; Timberlake, Lloyd (1987). Only One Earth: Living for the Future, BBC and Earthscan, London; and Anderson, D.M. and Grove, R.H. (eds.) (1987) Conservation in Africa: People, Policies and Practice, Cambridge University Press, Cambridge.

4 Harrell-Bond, B. (1985). "Humanitarianism in a Straightjacket", African Affairs, vol. 84, no. 2, pp. 3-14. 
sidelines of world discussion."5 The magnitude of problems and the failure of conventional economic thought and the bureaucracies to solve them has made SD widely attractive.

Literature on the Third World suggests that there are two distinct crises, of development and environment. The crisis of development, or the lack of it, is perhaps the better studied. It embraces the problems of debt, falling commodity prices, falling per capita food production, growing poverty and socio-economic differentials both within Third World states and between countries. The dimensions of the problems facing the Third World are substantial and real enough. The litany of statistics is grimly familiar. UNICEF has estimated that 15 million children die each year because of the inability to satisfy their basic human subsistence needs. A recent World Resources Institute study estimates that 20.4 million hectares of tropical forest are destroyed annually. Particularly affected by these increased rates, according to the WRI, are the forests of Brazil, Costa Rica, India, Myanmar, the Philippines, and Vietnam. Average population per doctor was 15,000 in low income countries in compared to 554 in the industrial North. ${ }^{6}$ Obviously, the accuracy and usefulness of aggregate statistics of this sort are limited.

5 Nyerere, Julius (1985). "Africa and the Debt Crisis", African Affairs, vol. 84 , no. 2, pp. 489-98.

6 UNICEF (1993). The Progress of Nations, UNICEF, New York, p. 6; World Resources Institute, World Resources 1990-1991, Oxford University Press, New York, p. 34; World Bank (1984). World Development Report 1984, Oxford University Press, New York. p. 25; 
Nonetheless, the overall picture of the essentially human dimension of the Third World's crisis is clear.

Analyses of the cause of the problems behind this crisis of development vary. On one side there is a great diversity of critical analysts, for example Lappé, Korten, and Frobel, who identify a crisis of "the world capitalist system as a whole, including much of the Third World too." 7 On the other side are the world financial institutions, spearheaded by the implacable economists of the World Bank. In 1984 they commented that the recession was over, having lasted from 1980 to 1983 the "longest in fifty years." However, it provided "many valuable lessons for economic policy because it highlighted long-standing weaknesses in every economy and in international arrangements", and had lessons to teach if recovery was to mature into "sustained and rapid growth of the kind the world enjoyed for twenty-five years after World War Two."8

One measure of the development crisis is Third World indebtedness. Unlike the previous shorter recession in 1974-5, the amount of foreign capital (in the form of aid or commercial loans) available to Third World countries declined rapidly after 1981, while the indebtedness rose. The external public debt of

\footnotetext{
${ }^{7}$ Frobel, F., J. Heinrichs, and O. Kreye (1985). "The Global Crisis and Developing Countries", pp. 111-24 in H. Addo et al. Development as Social Transformation: Reflections on the Global Problematique, Hodder and Stoughton, New York, p. 112.

${ }^{8}$ World Bank (1984). Op. Cit. p. 1.
} 
low income Third World countries (excluding China and India) rose from about 21 percent of GNP in 1970 to over 28 percent in 1982, with no less than seven countries having a debt of over 50 percent of GNP (Mauritania an unbelievable 146 percent; Togo, 104 percent; Mali, 79 percent; and Zaire, 78 percent). ${ }^{9}$ The situation in middle-income countries was if anything worse, with a significant rise in average indebtedness and debt larger than GNP in Mauritania, Costa Rica, and Nicaragua. There is also a significant relationship between the debt crisis and Third World poverty levels. 10

Set against the grim picture of intensifying debt in the early 1980s was the failure of agriculture to keep pace with foodgrain production. Sub-Saharan Africa was particularly hard hit, with intense droughts in the Sahel and elsewhere in the continent in the early 1970s and the early 1980s. Agricultural heavily favored those farmers using "green revolution" technology. The evidence suggests that per capita food production fell in sub-Saharan Africa consistently through the 1960s and 1970s.

The second crisis of the Third World is environmental. It embraces desertification and fuelwood shortage, and logging of tropical rainforest. Some analysts recognize a third crisis, of

\footnotetext{
${ }^{9}$ Ibid. p. 246.
}

10 For a discussion on Third World debt and the IMF see, Payer, Cheryl (1974). The Debt Trap: The IMF and the Third World, Monthly Review Press, New York; Oxfam America (1986) "Third World Debt: Payable in Hunger", Facts for Action 16. 
energy, separating out fuel and particularly fuelwood problems. ${ }^{11}$ These problems and others are widely reviewed and have become an important focus for environmental concern in the 1980s and 1990s. From 1972 the United Nations Environment Program (UNEP) published annual state of the environment reports on particular issues, and carried out a review of world environmental trends, ranging from atmospheric carbon dioxide and desertification to the quality of drinking water. These reports initially were deliberate attempts to address the problems of the Third World. The fundamental point was that development need not be impaired by environmental protection; integrated development planning and rational planning could resolve conflicts between environment and development. Furthermore, development was needed to improve the environment and this would require assistance, particularly money to pay for environmental safeguards, and reasonable prices for exports. ${ }^{12}$ Environment and Development

The danger of global crisis in development, environment and energy is a major theme of the Brundtland report. ${ }^{13}$ However, in practice, the fields of developmental and environmental studies

11 Peet, John (1992). Energy and the Ecological Economics of Sustainability, Island Press, Washington, DC.

12 Adams, William (1991). Green Development: Environment and Sustainability in the Third World, Routledge, New York, p. 38.

13 World Commission on Environment and Development (1987). Our Common Future, Oxford University Press, New York. 
are far from unified, often being remote from each other both conceptually and practically. So called "experts" rarely even claim expertise in both, and seldom understand linkages. ${ }^{14}$

Sociologically, the two fields have their own separate cadres, their own self-contained arenas of education and theory formation, their own technical language, research agendas and, their own literature. Each represents a distinct culture. Although the two cultures obviously overlap a great deal, and indeed make confident inroads onto each other's territory with scant regard for the exact meaning or purpose of terminology, there is rarely if ever any integration.

It is only within the last ten years that environment and development have been substantially linked. This has been done by arguing the need to set environmental resources and resource use in a social and political as well as an economic context. Radical political economy in particular offers a way of making the link.15 Why has this linkage been so elusive for so long? One reason is the mechanistic thinking and chronic tunnel vision of economists. This is backed up by parochial and doctrinaire thinking by radical theorists, constrained by "oppositionism" and "determinism."16

14 Chambers, Robert (1983). Rural Development: Putting the Last First, Longman, London, p.1.

15 Redclift, Michael (1987). Sustainable Development: Exploring the Contradictions, Methuen, New York.

16 Corbridge, S.E. (1990). Capitalist World Development: a Critique of Radical Development Geography, Macmillan, London, pp. 26-30. 
Behind this again lies a more general failure to cross disciplinary boundaries.

Development crises and environmental crises exist side by side in the literature, and together on the ground, yet explanations often fail to intersect. There are close and reciprocal links between development, poverty and environment. The complex and multidisciplinary nature of these links makes them difficult to identify and define. They often go unnoticed, fall down the cracks between disciplines, or get ignored because they fit so awkwardly into the structures of traditional academic analysis or discourse. Nonetheless, in the real world these links are real enough. They explain why development policy often causes rather than cure environmental problems. Development and environmental degradation often form a deadly trap for the poor.

Chambers argues that it is the plight of the poor that should set the agenda for development action, and in his approach to sustainability he directs attention to the concept of sustainable rural livelihoods, defined as the secure access to sufficient stocks and flows of food and cash to meet basic needs. He suggests that there are both moral and practical imperatives for making sustainable livelihood security the focus for development action. ${ }^{17}$ Ultimately that is what SD should be about. Thus, the debate about the environment in the Third Word, like that about development, is inherently political. It is an illusion to believe

17 Chambers, Robert (1983). Op. Cit., pp. 13-14. 
that environmental objectives stand apart from or can be met without engaging in politics

In exploring the relationship between development and the environment $I$ will construct a model of how it has changed over time: a historical account of the environment and development. Equally important, is the need to make clear the international linkages which provide the transformation momentum behind environmental change. These international linkages involve the transfer of capital, labor, and natural resources. The exploration of SD is concerned with all three: capital and labor, as well as the "natural" resources that human beings have altered through their own efforts. 18

In the pages that follow it will also be clear that the environment, whatever its geographic location, is socially constructed. The environment used by people in downtown Portland, Oregon, or hunters and gatherers in the Brazilian Amazon, is not merely located in different places; it means different things to those who use it. The environment is transformed by economic growth in a material sense but it is also continually transformed existentially, although we - the environmental users - often remain unconscious of the fact. A main function of this study is to evaluate the environmental change as a social process, inextricably linked with the expansion and contraction of the world economic system.

18 Smith, N. (1984) Uneven Development, Blackwell, London, p. 17. 
Since the late 1960s there has been considerable discussion of development, both as a concept and in concrete historical settings. Important differences exist between neo-classical and Marxist interpretations, and within each of these competing paradigms. In this thesis development is regarded as an historical process which links the exploitation of resources in the more industrialized countries with those of the South. The perspective adopted is that of political economy, in which the outcome of economic forces is clearly related to the behavior of people and the role of the state in accumulation. ${ }^{19}$ At the same time it is central to the argument of this thesis that development be subject to redefinition, since it is impossible for accumulation to take place within the global economic system without important environmental costs. $\mathrm{SD}$, if it is to be an alternative to unsustainable development, which will be addressed in the next chapter, should imply a break with linear models of growth and accumulation that ultimately may undermine the planet's life support systems. ${ }^{20}$ Development is too closely associated with what has occurred in Western capitalist societies in the past, and in a handful of peripheral capitalist societies today. To appreciate the limitations of development as economic growth one needs to look beyond the confines of industrialized societies in the North.

19 Redclift, Michael (1984). Development and the Environmental Crisis: Red or Green, Methuen, London, p. 15.

20 Korten, David (1991). "Sustainable Development," World Policy Journal, vol. 9, no. 1, pp. 157-189. 
It is essential to look at other cultures' concepts of environment and sustainability, including those of the technologically "primitive" societies which present-day development is undermining.

This thesis attempts to identify common elements in a political economy of the environment relating environmental change to "superstructural" factors, such as ideology and policy, and at different levels of political complexity. The intention is to provide a structural analysis of the environment in which the development process illuminates environmental change in different societies at both a philosophical and material level.

The structure of this study reflects the elaboration of this argument, beginning with the discussion of the concept of SD in chapter 2. In this chapter the origins and growth of SD are reviewed.

Chapter 3, examines the dimensions of the global environmental from the perspective of international political economy, arguing that the process of development cannot be divorced from the international economic system in a specific historical phase. It is international economic structures, as well as intellectual traditions, which impede SD.

Chapter 4 demonstrates how specific economic linkages have evolved between North and South, helping to establish environmental conditions for development and accompanying problems for Third World countries. This chapter then examines 
the explicit recognition that sustainability must be linked to development.

Chapter 5 takes a close look at the environment management approach which is directed at resolving, or reducing, the contradictions exposed by the development process. It discusses the relevance of environment management and conservation in developed countries for the experiences of developing countries. Improved analysis of both the impacts and the causes underlying environmental degradation remains crucial.

Chapter 6 examines the concept of sustainability. It places sustainability in the theoretical context underpinning SD. In the process I will directly explore the contradiction, widely associated with $\mathrm{SD}$, of economic growth being both the solution and the root cause of the problem.

Finally, in the conclusion, the argument is restated and reexamined, for its intellectual coherence. The thesis will concentrate on the way environmental issues are socially constructed under capitalism. If SD is founded on inconsistencies, how should they be resolved in practical policy terms? 


\section{CHAPTER 2. THE CONCEPT OF SUSTAINABLE DEVELOPMENT}

The concept of SD has a complex pedigree. It came in to widespread use when the World Commission on Environment and Development (WCED, also know as the Brundtland Commission) reported in 1987.21 However, it was the 1970s that saw the emergence of a major revision in development thinking that presented a fundamental challenge to the conventional consensus on development. In common with the call for a "basic needs strategy," this revision emphasized meeting the basic needs of the poor. 22 SD added the argument that "real" improvement cannot occur in Third World countries unless the strategies which are being formulated and implemented are environmentally sustainable over the long-term, are consistent with social values and institutions, and encourage "grassroots" participation in the development process. Thus, it is argued that "there will be no SD or meaningful growth without a clear commitment at the same time to preserve the environment and promote the rational use of resources." 23 Similarly, to be socially and culturally sustainable, "development must be gauged by the values [which] a society

\footnotetext{
21 WCED (1987), Op. Cit.
}

22 Stewart, Frances (1985). Planning to Meet Basic Needs, Macmillan, New York, pp. ix, 244.

23 Tolba, Mostafa (1987). Op. Cit., p. 12. 
itself, or some member thereof, deems to be requisite for its health and welfare." 24

The 1972 United Nations Conference on the Human Environment, held in Stockholm, is usually credited with popularizing the concept of $\mathrm{SD}$, although Caldwell suggests that the origins of the term probably lie in the Paris "Biosphere Conference" and the Washington, DC, conference on the Ecological Aspects of International Development, both of which were held in 1968.25 In general, the concern expressed at these conferences was that,

few if any countries take adequate account of environmental considerations when making policy or planning development. Few allocate or regulate uses of living resources so as to ensure that they are environmentally appropriate and sustainable. Many lack either the financial or technical resources, or the political will, or adequate legislative, institutional, or public, support for conservation (or any combination of these) to carry out fully the conservation measures required. 26

Whatever the origins of $\mathrm{SD}$, the Brundtland Commission was the political turning-point, making the concept one of geopolitical

${ }^{24}$ Goulet, Dennis (1971). The Cruel Choice: A New Concept in the Theory of Development, Atheneum, New York, p. 333.

25 Caldwell, Lynton (1984). "Political Aspects of Ecologically Sustainable Development, Environmental Conservation, Vol. 11, No. 4, pp. 299-308.

26 IUCN (1990). World Conservation Strategy: Living Resource Conservation for Sustainable Development, Gland, Switzerland: International Union for Conservation of Nature and Natural Resources, United Nations Environment Program and World Wildlife Fund). 
significance and the catch phrase it has become today. Since 1987, all manner of political leaders have talked about SD, and reams of paper have been published on the subject. SD as a concept has become devalued to the point where, to some, it is now just a cliché.

The manner in which the phrase SD is used and interpreted varies so much that while O'Riordan called SD a "contradiction in terms," 27 Redclift suggested that it may be just "another development truism." 28 These interpretational problems, though ultimately conceptual, have some semantic roots. Most people use the phrase "sustainable development" interchangeably with "ecologically sustainable or environmentally sound development." 29 In this interpretation, SD is understood as "ecological sustainability," and is conceptualized as a process of change that has (ecological) sustainability among its objectives.

Another problem in the literature occurs between what SD fundamentally involves and what is desirable in the pursuit of it. For example, participation in decision-making is held by some to be important in achieving SD. Yet democracy is hardly the most efficient -- albeit in the long run arguably the most equitable -mechanism for allocating scarce resources. Some suggest that this

27 O'Riordan, Timothy. (1985). "Future Directions in Environmental Policy," Journal of Environment and Planning, vol. 17 pp. 1431-1446. ${ }^{28}$ Redclift, Michael (1987). op. cit., p. 7.

29 Tolba, Mostafa (1987). op. cit., p. 64. 
politically expedient fuzziness will have to be overcome in favor of intellectual clarity and rigor, if the concept of SD is to be of fundamental importance. 30

However, such critiques miss a major point. The basic implication of the concept of $\mathrm{SD}$, as embraced by the Brundtland Commission and others, is that we should leave to the next generation a stock of "quality of life" assets no less than those we have inherited. 31 It is a political goal. But this can be interpreted in three ways:

- that the next generation should inherit such a stock of wealth comprising human-made assets and environmental assets;

- or that the next generation should inherit a stock of environmental assets no less than that inherited by the previous generation;

- or that the inherited stock should comprise human-made assets, natural assets and "human capital."

The first interpretation stresses all capital assets, human-made and "natural." The second emphasizes "natural capital" only. The third includes cultural and other human inheritances. Throughout recent history, human development has followed the pattern of the first interpretation. But as the human stresses of ecological functions are straining them to their breaking-point, so the

30 Lele, Sharachchandra (1991). "Sustainable Development: a Critical Review," World Development, vol. 19, no. 6, pp. 607-621.

31 Pearce, David, Markandya, Anil and Barbier, Edward (1989). Blueprint for a Green Economy, Earthscan, New York, p. 47. 
concept of "stock" should mature. Furthermore, the condition of "human capital" -- that is, society and its cultural inheritance -- is also at risk and must be built into any desirable concept of development. The powerful intuitive idea underlying the concept is that of intergenerational equity: our development is sustainable only to the extent that we can meet our needs without prejudice to those of future generations. This is similar in its intuitive appeal, although perhaps less emotionally charged, to concepts such as "freedom" and "justice." Even in those places where there is broad general agreement about what such terms mean, the actual achievement of human freedom, justice, and SD will be specific to local conditions and possibilities. 32

In any event, the practice of development that can be called sustainable on any basis is far behind the rhetoric. There is not enough empirical evidence or experience on which to base a solid definition. The meaning is itself evolving. SD is the intuitively sold "handrail that guides us along as we proceed toward development." 33 However, Edward Barbier sought to provide an analytical framework. ${ }^{34}$ It starts from the premise that development intrinsically involves trade-offs between conflicting

32 Holmberg, Johan, Bass, Stephen and Timberlake, Lloyd (1991).

Defending the Future - a Guide to Sustainable Development, Earthscan, New York, p. 11.

33 Lele, S. (1991). op. cit., p.610.

34 Barbier, Edward (1987). "The concept of sustainable economic development," Environmental Conservation, vol. 14, no. 2, pp. 101-110. 
goals, such as between economic growth and environmental conservation, introducing modern technology and preserving traditional culture, or reconciling growth with improved social equity. Given that many of the qualitative dimensions of the trade-offs cannot be accurately measured, the process inevitably becomes subject to judgment based on prevailing values and ethical norms. The process is dynamic with regard to space and time, and the trade-offs will differ between locations and time scales.

Barbier identified three systems as basic to any process of development: the biological or ecological resource system, the economic system and the social system. Human society applies a set of goals to each system, each with its own hierarchy of subgoals and targets. The objective of SD will then be to maximize goal achievement across these three systems at one and the same time through an adaptive process of trade-offs. It will not be possible to maximize all goals all the time, and there may be conflict among intra-system goals. Choices must therefore be made as to which goals should receive greater priority. Different development strategies will assign different priorities.

System goals could include the following:

Biological system goals

- Genetic diversity.

- Resilience.

- Biological productivity. 
Economic system goals

- Increasing production of goods and services.

- Satisfying basic needs or reducing poverty.

- Improving equity.

Social system goals

- Cultural diversity.

- Social justice.

- Gender equality.

- Participation. 35

Given the need for trade-offs between (and within) systems in interest of the greater whole, disciplined and consistent choices must be made as to which goals should receive priority in the development strategy. But the process of trade-offs among goals must be adaptive, for as individual preferences, social norms, ecological conditions, and so on, change over time, so must the relative priorities or weights assigned to various goals. Early on in the development process, conservation of the environment will mean protecting the natural resource base on which the economy depends, and this will require one set of policies and actions. Later on, the priorities for environment conservation will be different because more emphasis will be placed on minimizing the detriment of the industrialized society, again with different policies and actions. 36

35 The source for the system goals is ibid.

36 Tisdell, Clem (1988). "Sustainable Development: Differing Perspectives of Ecologists and Economists, and Relevance to LDCs," World Development, vol. 16 , no. 3 , pp. 377-384. 
The term SD, as posited by Barbier and others, suggests that the lessons of ecology can, and should, be applied to economic processes. It encompasses the ideas of the WCED, providing an environmental rationale through which the claims of development to improve the quality of life can be challenged and tested. To what extent, though, does SD provide an alternative paradigm, or system of meaning, as well as a focus for improving environmental policy and management?

In describing what he calls "co-evolutionary" development, Norgaard outlines possible linkages between economic and ecological paradigms. ${ }^{37}$ His intention is not to construct a new paradigm out of what remains of existing models, but to draw attention to the advantages of using different models simultaneously:

A linkage is quite different from a grand synthesis of previously incongruous paradigms. Through a linkage, each discipline enriches the other because of their differences. Neither discipline must abandon its past. Eventually, however, new emphases and approaches arise because of the enrichment...38

Norgaard calls his co-evolutionary approach a perspective, rather than a paradigm. This perspective takes issue with the way in which economics tackles environmental processes, attributing the

37 Norgaard, Richard (1989). "Sustainable development: A coevolutionary view," Futures, vol. 20, no. 6, pp. 606-620. See also, Norgaard, Richard (1984). "Coevolutionary agricultural development," Economic Development and Cultural Change, vol. 32, no. 3, pp. 343-366.

38 Ibid., p. 355. 
short-sightedness of many economists to their attachment to a mechanistic view of science. The implications of Norgaard's perspective are much more radical than the injunction to consider different disciplinary perspectives originally suggests.

SD requires a broad view of both economics and ecology, together with a political commitment to ensure that development is sustainable. The practical implications of such a position are important and cannot easily be avoided. Is it possible to undertake environmental planning and management in a way that does minimum damage to ecological processes without putting a brake on human aspirations for economic and social improvement? Does SD have a formal methodology? These questions await discussion in a later chapter. For the moment it remains to discuss the ways in which the SD approach accounts for the underlying inequalities that limit the livelihood opportunities of poor people and their environments.

One approach is that put forward by Farvar and Glaeser. ${ }^{39}$ They see SD as essentially political. The objective is not merely to identify the limitations of existing approaches; it is to advocate alternatives that deal effectively with "the power variable":

Naive statements on needs, participation and environmental compatibility are espoused in many papers...But whose needs are going to be met and whose are not; who will participate and who will not; and which lobbies, interest groups, and economic and

39 Farvar, M.T. and Glaeser, B. (1979). Politics of Ecodevelopment, Earthscan, New York, p. 141. 
political entities will be hurt by environmental compatibility? 40

Taking a long look at the practical commitment of international organizations to SD objectives, Farvar and Glaeser conclude that, even when fundamental approaches like land reform and restructuring of the relations of production have been considered in the agenda of such organizations, "the real issues have been obscured and neutralized by sterile language and wrong premises." 41 They attribute this ineffectiveness to a number of factors, among them budgetary cuts (for example, the budget of the United Nations Environment Program (UNEP) was halved between 1975 and 1979), and to the antipathy of various Western countries to any program based on self-reliance and the reduction of the South's technological dependence on the North. Clearly, advocating SD in principle does not commit governments or international organizations to its achievement in practice.

$\mathrm{SD}$ is also a term given to the planning concept advocated by UNEP. It was defined as "development at regional and local levels...consistent with the potentials of the area involved, with attention given to the adequate and rational use of the natural resources, and to applications of technological styles. ${ }^{42 "}$ This

40 Ibid., p.1.

41 Ibid., p.6.

42 UNEP (1984). General Assessment of Progress in the Implementation of the Plan of Action to Combat Desertification, UNEP, New York, p. 6. 
usage suggests a regional focus for resource planning, informed by technological considerations. It is a long way from the ethically committed, integrated approach suggested by Jacobs and Munroe. ${ }^{43}$

Dasmann also departs from UNEP's planning approach by advocating a definition of SD that is little short of moral renewal and self-sufficiency: "to somewhat simplify sustainable development, I have considered it to be represented by a triangle, one side of which is basic needs, the second self-reliance, and the base ecological sustainability." 44 Each of these variables needs to be considered, since development will not be sustainable unless poor people are involved in meeting their aspirations. As Chambers has expressed it, what is required is that "last" thinking is adopted, putting people first and poor people and their priorities first of all. "The environment and development are means, not ends in themselves. The environment and development are for people, not people for environment and

43 Jacobs, P. and Munroe, D. ,eds., (1987). Conservation with Equity: Strategies for Sustainable Development, proceedings of the Conference on Conservation and Development: Implementing the World Conservation Strategy, Ottawa, Canada, May 31-June 5, 1986, IUCN, Gland, Swizerland. "Sustainable Development seeks...to respond to five broad requirements: (1) integration of conservation and development, (2) satisfaction of basic human needs, (3) achievement of equity and social justice, (4) provision of social self-determination and cultural diversity, and (5) maintenance of ecological integrity." p. 6

44 Dasmann, R.F. (1985). Achieving the Sustainable Use of Species and Ecosystems, Wiley, London, p. 215. 
development."45 In Chambers' terminology SD is a "first" concept, since it was first conceived. In his view the poor are largely concerned with their immediate livelihoods; it is the enlightened rich who give priority to sustainability. What is required is a mental leap along the lines of "sustainable livelihood thinking."46 He contrasts "environment thinking" with "development thinking" and "livelihood thinking." The perspective of the poor is at variance with that of most economists and biologists, placing the immediate satisfaction of needs and the avoidance of risk before sustainability or higher productivity. Similarly the time horizon of the poor is shorter, the future valued much less than the present. According to Chambers, "sustainable livelihood thinking" enables causal connections to be made between development and livelihoods and between the environment and livelihoods. What poor people pursue through the development process and their use of the environment is, simply put, a better livelihood.

The perspective advocated by Chambers is a real advance on much of the "institutional" writing about SD. The concept has both economic and ecological parameters which are difficult to marry. Dissatisfaction with the narrowness of the ecological model has led to attempts to steal or borrow some sociological content, either through social planning norms (UNEP's use) or through referring

45 Chambers, Robert (1986). Sustainable Livelihoods: An Opportunity for the World Commission on Environment and Development, Oxford University Press, New York, p.7.

46 Ibid., p.10. 
to "basic needs" and "self reliance." Chambers criticizes the suggestion that we are in a better position than the poor to recognize what is good for them, an assumption contained in much of the "basic needs" writing. $47 \mathrm{He}$ asserts that "short-term improvements in living create conditions for later livelihoodintensive human use of the environment which is sustainable." 48 Human welfare should be the point of departure.

The nagging doubt remains, however, that despite the seriousness of Chambers' position, it does not represent an adequate response to the issue raised by Farvar and Glaeser. For SD to become a reality it is necessary for the livelihoods of the poor to be given priority, but how can this priority be pursued at the local level while the effects of international development systematically marginalizes them? The political aspects of development extend to SD options which can only be achieved through political changes at the local, national, and international level. Chambers believes that "political economy" can be incorporated in his approach by examining the net effect of

47 For a description of the "basic needs" approach, see List Franklin, "Conventional development strategies and basic needs fulfillment," reprinted as Reading 5 in Todaro, Michael ed. (1983).The Struggle for Economic Development, Longman, New York; and P.K. Ghosh, ed. (1984). Third World Development: A Basic Needs Approach, Greenwood Press, Westport, Conn. For an attempt to specify and quantify the concept of basic needs, see ILO, Employment, Growth and Basic Needs, International Labor Organization, Geneva. A similar view with a focus on the notion of "entitlements" can be found in Sen, Amartya (1983). "Development: Which way now?" The Economic Journal vol. 93 December, pp. 754-757.

48 Ibid., p.13. 
transnational corporations and logging contractors on sustainable livelihoods. However, these interests are often determining factors in the availability, or otherwise, of sustainable livelihoods. It is necessary to put political economy first when applying realworld thinking to the priorities of the poor. As will be demonstrated in the next chapter, unless the mainstream conception of $\mathrm{SD}$ is pitched at a level which recognizes international structures, it is in danger of being yet another discarded development concept, like "appropriate technology." Its polemical usefulness will have outlived its practical utility. 


\section{CHAPTER 3. SUSTAINABLE DEVELOPMENT AND THE INTERNATIONAL POLITICAL ECONOMY}

Documents advocating SD, such as the World Conservation Strategy and WCED, fail to come to grips with the central issue of economic growth as the motor behind development. 49 The previous discussion of SD was principally addressed to the negative consequences of development. This chapter will cover the problem of economic growth and the environment specifically in societies of the South. The analysis is directed towards identifying those features of the international economy -- trade, aid policy, the debt crisis and the behavior of multinational corporations -- that carry negative implications for the long-term sustainability of the development process.

\section{Economic growth and world trade}

Most development economists and international agencies take the view that without fairly free international trade it is extremely difficult to see how all but the largest developing countries will be able to get sustained economic growth under way, as previously discussed. The classical case is that the "gains from trade" outweigh the losses. However, this approach to trade and development fails to address some serious issues. First, even the textbooks on

49 WCED (1987); Jacobs, P. and Munroe, D. ,eds., (1987). 
international-trade theory acknowledge that the gains may be very unevenly divided as between countries or trading blocs, depending on their relative economic "muscle" and their disposition to employ this power.

Second, Classical theory also acknowledges that there will be losers as well as gainers. However it does not identify a process at work which will "equalize" these advantages/disadvantages to individual countries.

Third, Orthodox definitions of development imply that economic growth is broadly beneficial and that freer trade will stimulate growth. However, the assertion that economic growth is beneficial for whole societies can be questioned. Similarly, without calculating the environmental and social consequences of growth, it may be a mistake to pursue growth rather than "development" in a wider sense.

The concentration on growth has obscured the fact that resource depletion and other aspects of unsustainable development are direct consequences of growth itself. Where agencies like the World Bank have made loans to promote highgrowth sectors, the environmental and social consequence have often been disastrous. For example, as discussed later in this chapter, the effects of ranching in the humid tropics have usually proved negative in both social and environmental terms. The returns on capital represented by investment in ranching obscure the progressive squandering of a unique global asset--tropical 
ecosystems and the people who live in harmony with them, which are frequently excluded from the calculation. Conventional economic development identifies the optimal conditions for exploiting resources, a rather different process from considering sustainable development. The different dimensions of sustainability - social, environmental and ethical - are an essential part of the development debate, but ones which the concern with "growth" often leads one to miss.

If the existence of international trade in the modern world is essential to economic growth in less developed countries, it has also ensured that natural resources are exploited for short-term profit. Deteriorating terms of trade for poor countries have contributed to the clearing of rain forests to make way for exportled stock-raising. Similarly, a poor balance-of-payments position is likely to contribute to a country's over-dependence on fuelwood, especially given the high costs of petroleum-based energy. 50 Alternatively, a fall in price, in relative terms, for key commodity crops usually increases the use of land for these rather than for food crops, and this in turn increases food imports into countries that could be self-sufficient. The point is that decisions over the use to which natural resources are put are clearly influenced, directly and indirectly, by the trading patterns established by the developed countries. Environmental problems are not reducible to international economic relations, but they

50 Smith, N. (1984). Op. Cit., p. 20. 
would not have assumed their present gravity if the developing countries had been able to practice the sustainable-resource methods which often formed part of their traditional systems. ${ }^{51}$

It is within this context, in which sustainable practices have been neglected in favor of closer economic dependence on Northern technology and markets, that one needs to understand the current environmental crisis. For example, advising African countries on how to develop their resources has become a major industry, with European and North American consulting firms charging as much as $\$ 180,000$ for a year of the professional expert's time. In 1985 more than half the $\$ 7-8$ billion spent yearly by development donors in Africa went to finance the 80,000 expatriates working for public agencies under official aid programs.52 It may reasonably be asked who is providing development assistance to whom under these circumstances.

Awareness of the serious nature of Africa's environmental crisis has done little to alter the approach of international development agencies. The World Bank's 1881 "Berg Report" on Africa advocates export-led development as a development priority, rather than goals such as self-sufficiency in food.53 The

51 Barbier, Edward (1989). "Sustainable Agriculture on Marginal Land: a Policy Framework," Environment, vol. 31, no. 9, pp. 13-17, 36-40.

52 Timberlake, Lloyd (1985). Africa in Crisis, Earthscan, London, p. 8.

53 Lewis, Stephen, Jr. (1986) “Africa's Trade and the World Economy," in Robert Berg, and J. Seymour Whitaker (eds.) (1986). Strategies for African Development, University of California Press, Berkeley, p. 490. 
solution to Africa's growing external debts, debts like those which have already made a deep impact in Latin America, is held to be the "East-Asian model" of export-led performance: Taiwan, South Korea, Hong Kong. The Berg Report recommended cutting government subsidies and privatizing the public sector of most African countries with debt problems as a solution to African insolvency. Interestingly, the emphasis in explaining these problems was placed squarely on "environmental" causes and population increase rather than on externally induced structural problems. 54

Export-led development, however, is a perilous, if not impossible, route for most African countries at a time of economic uncertainty in the North and worsening international terms of trade for the South. Africa is likely to experience what Latin America already knows: that private banks can only get repayments on their loans if they lend more money to the debtor. The alternative of a debt moratorium is still considered by most countries a much greater risk than defaulting. Most African countries are agreed that food sufficiency should be their continental goal, but they are almost powerless to achieve it while they are saddled with the need to increase export income. How, they ask, can we export more to the developed countries, as the International Monetary Fund (IMF) and the World Bank recommend, when the developed countries are trying to restrict

54 Ibid., pp. 488-489. 
their imports? Faced with the need for "structural adjustment", they ask the question put by Susan George:

If the International Monetary Fund believed (which it patently does not) that economic growth can also result from greater social equality, access to education, health-care and other basic services, fairer income distribution etc., it could make such objectives part of its programs. 55

These agencies see their primary role as that of guaranteeing the maintenance of the trade process which contributed to the developing countries' indebtedness in the first place.56 Granted there is some change from within these organizations over the last few years. The capacity of the South to mount long-term sustainability is a problem both for the less developed countries which are most "developed" (the bigger countries in Latin America, and some in East Asia) and those which are least developed (the Sahelian countries, Bangladesh, Haiti). For the first group of semi-industrialized countries, rapid economic growth has meant that they have inherited many of the environmental problems of the "rich world" in an exaggerated form. For the second group declining per capita incomes and resource exhaustion have led to mass migration, the resettlement

55 George, Susan (1985). The Debt Crisis, The Other Economic Summit, London, p.3.

56 Rich, Bruce (1994). Mortgaging the earth: The World Bank, environmental impoverishment, and the crisis of development, Beacon Press, Boston, pp. 182-200. 
of populations, increasing population pressures and frequently financial bankruptcy. In both cases the form of their insertion within the international economy has reduced their capacity to solve their own environmental problems.

There is significant evidence that the world market is an enemy to Third World Countries. Almost all Third World countries are dependent on exporting minerals and cash crops. While real prices in the world market for these commodities have declined during the post-World War II period, the prices of manufactured imports from industrialized countries have steadily increased. 57

Throughout sub-Saharan Africa, low commodity prices have affected markets and local communities that depend on a very narrow range of exports. Most Third World countries find themselves in what Oxfam calls a "trade trap" where they are forced to produce cash crops for income that is so low, they continue to live their lives in abject poverty. 58

In Cote d' Ivoire, exports of coffee rose by 26 percent in volume but fell by 21 percent in value between 1988 and 1990.59 Similarly, in Rwanda, export earnings declined by 50 percent

57 Coote, Belinda (1992). The Trade Trap: Poverty and the Global Commodity Markets, Oxfam, Oxford, p.8.

58 Ibid., ix.

59 UNICEF (1993). The Progress of Nations, UNICEF, New York, pp. 50-51. 
between 1987 and 1991.60 A recent study demonstrates that under the Uruguay Round of the General Agreement on Tariffs and Trade (GATT), Africa will economically suffer under the new agreement. With the loss of special trading rights with the European Community (EC) and cuts in agricultural subsidies, it is estimated that Africa will lose an additional $\$ 3$ billion in trade income each year. ${ }^{61}$

The deterioration of Africa's terms of trade means that most African governments have been forced to spend more in the world market than they earn. They have filled this gap by borrowing. By 1992, external debt for sub- Saharan Africa was over $\$ 200$ billion, a debilitating number that represents 109 percent of its GNP, an 80 percent increase since 1980.62 The World Bank has concluded that "the bite that debt-service payments take out of a country's capacity to import each year is clearly unsustainable in an environment of low investment and stagnant GDP."63

Forced to produce foreign-exchange earning crops to pay off unpayable debts, African nations find themselves importing more

60 Ibid., p. 52.

61 Ritchie, Mark, (1994) "GATT Facts: Africa Loses Under GATT", Institute for Agriculture and Trade Policy, March 1994. pp. 45-58.

62 World Bank (1993). Social Indicators of Development 1993, The Johns Hopkins Press, Baltimore MA, p. 29.

63 Ibid. 
and more food. Food imports, currently estimated at 10 percent of total imports, place considerable strain on Africa's balance of payments. 64

The combined effect of the World Bank, the IMF and United States government borrowing has been to maintain high interest rates, to increase pressure on Third World countries to export more and consume less, and to starve much of the developing world of much needed capital. The costs of United States government debt policy are particularly painful in countries like those of sub-Saharan Africa, where more than 60 per cent of export earnings come from commodities for which the price elasticity of demand is such that an increase in export volume (urged by the IMF and the Berg Report) would actually reduce export earnings.65 Without altering fundamentally both the way the debt is managed, and the policies of the industrial countries towards trade and investment in the South, export-led solutions threaten to put at risk many of the achievements of post-colonial administration.

The solution to these problems is not global economic growth, in the language of the Brandt Report, for the struggle to effect such growth might in itself be damaging to the poor who are already paying the price for structural "adjustment." The

64 UNDP (1994). Human Development Report 1994 Oxford University Press, New York, p. 55.

65 Godfrey, M, (1986) in T. Rose (ed.) Crisis and Recovery in Sub-Saharan Africa, OECD, Paris, p. 178. 
pursuit of economic growth, unchecked by environmental considerations, can accelerate, among other things, topsoil losses, the scarcity of fresh water, and the deterioration of grassland and deforestation. These apparently inexorable processes are a consequence of policies long advocated for Africa and Latin America: increase exports, buy in expertise from foreign consultants, construct big dams, bring more land under exportcrop production. The irony is that these policies not only have negative environmental consequences, they also frequently fail to meet their economic objectives. ${ }^{66}$ The unsustainable utilization of resources for short-term "growth" objectives might ultimately fail to bring about economic growth itself.

Finally, it is sometimes argued that population pressure is the major obstacle to securing development in the South, as if limiting population could be divorced from the strategies poor people adopt in pursuing their livelihoods. Reference is made to how increasing family size will prevent human needs being met, when large families are precisely one of the strategies open to the poor to ensure their own survival. What needs to be recognized is the major influence of socio-economic conditions, the vulnerability as well as the absolute poverty of people, on the number of children in the family. The benefit children provide to parents in most third world countries cannot be measured just by hours of

66 Repetto, Robert (1990). "Environmental Productivity," Challenge, vol. 33, no. 5, Sept-Oct , pp. 33-48. 
labor and/or income for the family. The intangibles are just as important. Bigger families carry more weight in community affairs. In the third world, with no reliable channels for advancement in sight, parents can always hope that the next child will be the one clever and bright enough to get an education and land a city job despite the odds.

Consider the implications of the following World Bank population statistics covering three-fourths of the world's people who live in 72 countries that the bank designates low and lowermiddle income. 67

While average annual population growth rates in all industrial countries have been below 2 percent a year for decades, in these 72 countries only six had reduced their population growth below 2 percent by 1982.68 Of these, only four have experienced a dramatic drop in their growth rate since the 1960s: China, Sri Lanka, Cuba, and Colombia. (Although not a country, and therefore not listed in the World Bank statistics, the Indian state of Kerala also reduced it population growth rate

67 World Bank (1984). The World Development Report 1984, Oxford University Press, New York, table 19.

68 Technically Lebanon should be added to this group of six; its growth rate fell from 2.9 percent to .5 percent between 1960-1982. The extreme disruption of the country no doubt is a major contributor and limits the usefulness of including it in any general discussion of population successes. Also note that the World Bank does not include several island countries like Grenada and Mauritius that also have growth rates below 2 percent. 
below 2 percent. ${ }^{69}$ ) Population growth in these four exceptional countries and in Kerala has slowed at twice the rate of the current industrialized countries during their transition from high to low growth. ${ }^{70}$ What do these exceptions tell us? What could societies as different as those of China, Sri Lanka, Cuba, Colombia, and Kerala have in common? Except Colombia, they have all assured their citizens access to a basic diet through more extensive food guarantee systems than exist in other third world societies.

In most of these societies, income distribution is also less skewed than in most other countries. The distribution of household income in Sri Lanka, for example, is more equitable than in Indonesia, India, or even the United States. ${ }^{71}$

The positive link between fertility decline and increased income equity is confirmed by empirical investigations. While one might question the possibility of such neat precision, one World Bank study of 64 different countries indicated that when the poorest group's income goes up by one percentage point, the general fertility rate drops by almost three percentage points. ${ }^{72}$

69 Census of India, Kerala State, Part2A, Statement 3 and 8, pp. 28 and 32. As quoted in Lappe, F.M. and Schurman, Rachel (1990) Taking Population Seriously, Grove Press, San Francisco, pp. 120-1. According to the Indian Census, the population growth rate of Kerala averaged 1.8 percent annually between 1971 and 1981.

70 Murdoch, William (1980). The Poverty of Nations, Johns Hopkins University Press, Baltimore, p. 89.

71 World Bank (1984). The World Development Report 1984, Oxford University Press, New York, table 28.

72 World Bank (1974). Population Policies and Economic Development, Johns Hopkins University Press, Baltimore, Appendix A, p. 147. The study 
When literacy and life expectancy are added to the income analysis, the three factors explain 80 percent of the variation in fertility amount countries. ${ }^{73}$

The conventional argument about population growth could be reversed: efforts to slow down population growth will continue to be frustrated until meeting basic human needs is considered the priority of development.

\section{Aid and the monetization of local economies}

Few international issues have focused as much attention as aid, but, often the discussion of development aid is divorced from a consideration of long-term environmental effects. Apologists for aid, especially food aid, have powerful ideological support in popular assumptions which link helping people in the Third World with general "neighborliness."

There are many popular misconceptions about aid. Aid, especially bilateral aid between countries, is not directed simply to alleviating hunger and poverty. Even if it has a net effect which is advantageous to the poor, for whom much of it was intended, it is often more beneficial to the better-off in Third World countries. ${ }^{74}$ By reducing peoples' capacity to manage their

also controlled for per capita GNP differences. The poorest groups here refers to the bottom 40 percent of the population by income.

73 Ibid.

74 Ruchelshaus, William (1989). "Toward a Sustainable World," Scientific American, vol. 261, no. 3, Sept. pp. 166-174. For more global effects of U.S. foreign aid see Lappe F.M., Collins, Joseph, and Kinley, David (1981), Aid As 
own environment on a sustainable productive basis, aid may contribute to the problem it was intended to address. Food aid, in particular, can increase food dependency and remove responsibility for the environment from those who have most to gain from its beneficial long-term management. This was succinctly expressed by a Senegalese farmer in the following way:

We don't want to be called bush people. We are citizens like everyone else. We want to be free to sell to whom we choose, and to buy from whom we choose. We too want to set our own prices. No one ought to make us concentrate on cotton: we should grow what we think is best for us. They tell us to follow their programs and we'll get their assistance, and when we follow that program the prices of their ploughs double and the prices for our crops stay the same. ${ }^{75}$

Most donor countries, in a position to give aid, give it to countries with which they are politically sympathetic. Egypt, Israel and Turkey between them receive four-fifths of all United States bilateral aid, in 1990. A few countries receive a significant amount of United States bilateral aid without much military assistance (India, Indonesia and Bangladesh among them), but even this combined total adds up to no more than the United States gives Egypt in military spending, and not much more than

Obstacle: Twenty Questions about our Foreign Aid and the Hungry. Grove Press, San Francisco; and Lappe, F.M., Schurman, Rachel, and Danaher, Kevin (1987). Betraying the National Interest, Grove Press, San Francisco

75 Rose, S., R. Lewontin, and L. Kamin (1984). Not in Our Genes: Biology, Ideology and Human Nature, Penguin, New York, p. 16. 
half what it gives to Israel. ${ }^{76}$ Aid does not simply have political strings: it is clearly important as part of global political strategies. It is clear that aid is not given to those who need it most, but to those whom the aid-givers choose for political and strategic reasons, rather than the eradication of poverty.

Aid also distinguishes unfairly between those who receive it. For example, in 1983 Ethiopia had the lowest annual per capita income in Africa (only $\$ 140$ ) but received a mere $\$ 8$ per capita in aid. Neighboring Somalia, where incomes per head was twice as high, received for its friendship with the West about ten times as much aid per capita in 1984 . There is evidence too that cash handouts tend to reach those farmers who are well connected, rather than those in greatest need, reinforcing public skepticism in developed countries, when it is exposed. 77

Within Third World countries aid is rarely concentrated on the services that benefit the poorest. The World Bank reckons that, of all the aid going to low-income countries in 1988, a mere 2 percent went to primary health care and 1 percent to population programs. ${ }^{78}$ Even the aid that is spent on health and education

76 Patten, Christopher (1990). “Common Future- Common Challenge: Aid Policy and the Environment," in D.R. Angell, J.D. Comer, and M.L. Wilkinson (eds.) Sustaining Earth: Response to the Environmental Threat, St. Martin's Press, New York, pp. 135-152; see also, The Economist, "A Survey of Third World Finance: New Ways to Grow," Sept 25, 1993, pp. Survey 1-43.

77 Ibid. p. 137.

78 The Economist, "What's wrong with foreign aid?" May 7, 1994, pp. 19-22. 
tends to go to services that benefit disproportionately the betteroff. Aid for health care goes disproportionately to hospitals (in 1988-89, for instance, 33 percent of Japan's bilateral aid for health went to building hospitals); aid for education, to universities. In sub-Saharan Africa in the 1980s, only $\$ 1$ of official development assistance went on each primary pupil; $\$ 11$ on each secondary pupil, and $\$ 575$ on each university student. 79

Food aid, like much aid in general, helps strengthen the position of urban workers and urban elites at the expense of rural groups. 80 By making cheap imported food available it also acts as a disincentive to local farmers to produce. Where they can, they avail themselves of food aid. It also, and this is a critical issue, changes the diet of the poor, introducing them to highly valued imports like wheat bread, at the expense of indigenous food grains and root crops, millet, sorghum and cassava. The shift in tastes reduces demand for the local farmers' produce which in turn holds down the prices local farmers receive. The neglect of basic agricultural research into the crops grown by small farmers, one of the abiding weaknesses of African development policy, completes the vicious circle of poverty. 81

79 World Bank, (1992). Effective implementation: Key to Development Impact

(The Wapenhans Report), World Bank, Washington DC, p. 110.

80 Lipton, Michael (1977). Why Poor People Stay Poor, Temple Smith, London, p. 48.

81 Hayter, T. and C. Watson (1989). Aid: Rhetoric and Reality, Pluto, London, p. 31 . 
The Green Revolution in Asia was a dramatic example of the way that the production of food programs could be increased through improved seed varieties and heavy dependence on chemical fertilizers and pesticides. The increases in aggregate production which followed enabled some countries, like India, to build up national buffer stocks of food staples, ensuring that they would not experience shortfalls like those of 1971, when over one million died because food was not available. However, the ecological effects of this Revolution are being counted today, two decades after it got under way. They include the salinization of irrigation water, the polluting effects of chemical sprays, and the increasing resistance of pest species to insecticides. The total environmental cost is even greater, and account should be taken of the narrowing of popular diets, the increased vulnerability of small farmers to indebtedness, and the external dependence of oil-importing countries (like India) on outside suppliers. The Green Revolution has proved to be a mixed blessing. 82

Most of the technical assistance that has gone into African and Latin American agriculture has been directed at producing cash crops for the international market. The Green Revolution has mixed effects, but it was at least targeted at food crops. Cash crops earn foreign exchange to pay for capital goods, intermediate goods, and oil. Increasingly cash crops pay off the interest on the

82 Johnston, B.F. and W.C. Clark (1982). Redesigning Rural Development: A Strategic Perspective, Johns Hopkins University Press, Baltimore, pp. 1023. 
external debt that was itself incurred largely through the acquisition of prestigious and capital-intensive development infrastructure. This is another vicious circle, made up not of the producers and consumers of food, but of the producers and consumers of transnational technology. The contrasts between Latin America and Africa and many parts of Asia are vivid. Inevitably, Africa has become a food-dependent continent as a result. Cereal imports rose to 32 million tons in 1984, when African farmers themselves were able to produce less than twothirds of the continent's cereal needs. According to the Food and Agricultural Organization, Africa will be growing just over one half of its own cereal needs by the year 2000.83

Cash crops have also contributed to the monetization of local economies. By "local economies" is meant the system of production and distribution that local people manage themselves. Within local economies the labor of women, in particular, is as undervalued in financial terms as it is essential in livelihood terms. The impact of market forces women's labor is taken for granted, and the labor process is transformed, to the benefit of men. Women's responsibility for reproduction as well as production places them in a disadvantageous position in relation to new market opportunities. It is women who nurture the children, feed the family and provide much of the "casual" paid labor which

83 As quoted in Timberlake, Lloyd (1985). Africa in Crisis: The Causes, The Cures of Environmental Bankruptcy, Earthscan, New York, pp. 51-68. 
underpins commodity production for the market. It is also women, critically, who interact most closely with the natural environment: collecting the fuelwood, carrying the household's water long distances, tending the vegetable garden. Women therefore bear the brunt of environmental degradation, through their proximity to and dependence upon the environment, while also being held responsible for this decline. Unable to reverse the erosion of resources to which the household has access, women are placed in the impossible position of acting as guardians of an environment which is as undervalued and exploited as their own labor. ${ }^{84}$

The effects of an increase in commodity production for the market and the family's dependence on wage labor fall disproportionately on women and, through them, the environment. Male involvement in the monetized sector is invariably greater than that of women across a range of rural societies. Similarly, women bear major responsibility for intensive non-mechanized production at one end of the food system, the end which is casually ignored by large-scale development projects. At the "other" end of the food system it is usually women who look after food-processing, storage and family nutrition, activities that are increasingly displaced from the household by the "development" process and relocated in commercial, agroindustrial plants controlled by men. It is essential to recognize

84 Ekins, Paul (1992). op. cit.; see also, Sebstad, Jennifer (1990). Women and Self-reliance in India: The SEWA Story, Zed, London. 
that the loss of primary environmental control by rural households is bound up with the marginal status and declining economic power of women. 85

What are the specifically environmental effects of development aid? Can one make connections between the economic and social costs of large-scale development planning and the disintegration of the rural environment in so much of the South? The answer is that one can but that the connections are often obscured by the superficial attraction of large projects. As Bruce Rich reports:

Projects involving the spraying of vast areas with massive amounts of hard pesticides that are often banned in Western countries, projects involving the construction of big hydropower and perennial irrigation schemes which require the removal of large populations on to infertile land, with no proper compensation, and which must inevitably lead to widespread waterlogging and soil salinization as well as the spread of waterborne diseases. ${ }^{86}$

In 1988 the four Multilateral Development Banks (World Bank, Inter American Development Bank, Asian Development Bank and African Development Bank) allocated over half their project loans to work in environmentally sensitive areas, such as agriculture, rural development, dam and irrigation schemes. But they

85 Momsen, J.H. (1991). Women and development in the third world, Routledge, London, pp. 6-15.

86 Rich, Bruce (1985). "Multilateral Development Banks-Their Role in Destroying the Global Environment," The Ecologist, vol. 15, no. 2, p. 56. 
employed an absurdly small staff to oversee the "environmental consequences" of their work. The Office of Environmental and Scientific Affairs of the World Bank employs a "minuscule" staff to review the prospective environmental impacts of most of the Bank's 315 projects. Evidence from within this office is eloquent testimony to the cursory way in which environmental impacts are treated. 87

This environmental degradation cannot simply be reversed. Land under vegetation absorbs more heat than bare sandy soil. Thus, when there is plant cover, the ground is warmer. Consequently, there are more vigorous thermal undercurrents which take moisture, provided by that very plant cover, up to high altitudes where it condenses. Overgrazing strips vegetation and leads to a new stable state of bare cool soil, lower rainfall and sparse vegetation. According to a report in The New York Times, "although the verdict is not wholly certain it is possible that parts of the western Sahel have already switched to a new lower rainfall regime." 88 Environmental factors are important, not because political and economic policy cannot change them, but because they do.

\section{Debt and interest rates}

87 Hayter and Watson (1989). op. cit., p. 112.

88 New York Times, October 18, 1985, p. 11. 
It is difficult to exaggerate the magnitude of the debt crisis. In 1986 Mexico, which earns more in foreign exchange from oil than all its other exports put together, is expected to spend its entire revenue from oil in paying off the interest on its external debt. The Mexican government also borrows at home and pays interest on this domestic debt. In 1985 almost two-thirds of the Mexican government's income was spent paying off this domestic debt, leaving just over a third to meet total public expenditure. As Mexico has become more indebted, so the IMF and the international banks, which are its creditors, insist that the government open up the Mexican economy to foreign investment, sell off publicly owned companies and reduce subsidies, especially on food. The last measure is particularly perverse in its effects. As subsidies are withdrawn, inflation increases, interest rates rise further, and the Mexican government pays more to finance its debt.

The situation in Africa is less severe in terms of the absolute magnitude of the debt, but in relative terms it is probably worse. In 1983 there were no African countries among the big debtors. By 1985 the total external debt of the 42 sub-Saharan economies was in the order of $\$ 130-135$ billion. The true average debtservice-to-exports ratio in these countries, excluding debt arrears and rescheduling, was about 35 per cent in 1985.89 This is less

89 Cheru, Fantu (1989). The Silent Revolution in Africa: Debt, Development, and Democracy, Zed, London, pp. 22-45. 
than in many Latin American countries-- Brazil, Mexico, Chile and Argentina are spending most of their export earnings on debt interest-- but it is more critical in Africa for another reason. Put starkly, much of sub-Saharan Africa is literally starving while debt interest is being paid.

The case of the Sudan in the mid 1980s is illustrative of what is happening in Africa. The Sudan had a $\$ 78$ million proposal for emergency aid and $\$ 213$ million in interest due, after rescheduling on $\$ 10$ billion of external debts. Paying interest at this rate, for a poor country like the Sudan, means effectively cutting grain imports needed to avert starvation or fuel imports needed to keep the economy operating. In the words of a recent report, a failure to alter the existing debt imbalance will mean in human terms for most Africans increased political and social instability (or worse), severe deprivation for a majority - and premature death for hundreds of thousands a year. 90

It is worth remembering how the debt crisis arose in the first place. After the first oil shock in 1973 there was a fourfold increase in oil prices. The OPEC countries invested their large export surpluses in the Euro-currency market and the international banks. At that time conditions for borrowing were easy and the banks wanted to lend. It was also profitable to borrow because interest rates were low compared with world inflation figures. Interest rates were often negative in real terms.

90 Ibid., pp. 102-125. 
World inflation figures also cut the value of the accumulated debt. The banks then set about lending money enabling developing countries to "adjust" to the effects of oil price rises. But, adjustment is often a euphemism for policies which imply a drop in living standards. 91

The real crisis came after the second oil shock in 1979. Just when debtor countries needed credit, they found high realinterest rates, and the availability of credit from OPEC also declined. By August 1982 the Mexican debt crisis forced the IMF, the United States government and the private banks to assemble a huge debt-rescue package. Other countries followed, in Latin America and elsewhere. Accompanying the increased debts was an overvalued dollar-exchange rate which undermined national currencies and led to the flight of capital: over $\$ 11$ billion dollars left Argentina in 1981/2; $\$ 17$ billion left Mexico in the same period. 92

Given the sacrifices implied by structural adjustment policy, it may well be asked what prevents debtor countries from defaulting completely? If payments on the debt are suspended (moratorium), the costs to the 30 or so international banks which have benefited from high interest rates would be serious. It would

91 Payer, Cheryl (1989). "Causes of the debt crisis," in Onimode, Bade (ed.) The IMF, The World Bank and The African Debt: The Social \& Political Impact, Zed Books, London, pp. 8-16.

92 O'Brien, Paul (1986). “ The Debt Cannot be Paid," Bulletin of Latin American Research, vol. 5, no. 1, pp. 12-36. 
have cost them billions, had payments been suspended, making a considerable impact on United States capital markets. If there were a debt default, the United States banks involved could be ruined. It is not surprising, then, that the banks (the IMF and Northern political leaders) favor the idea of debt rescheduling. This brings them rescheduling fees, it spreads the interest rate and it protects their assets at book value.

The short-term solutions that have been found to the debt crisis are obviously good for the banks, but the more critical question is what they imply for the debtors. O'Brien argued in the mid 1980s that Latin American countries, at least, should seriously consider the advantages of a co-ordinated default. 93 The way that you interpret a managed solution to the debt depends on what you think are the prospects for the world economy. An objective assessment would hardly lead to optimism. The United States is the best example of a rich country engaged in deficit financing to maintain consumption levels. In 1985 Susan George commented on the fact that the United States, with a population of 220 million owed nearly $\$ 6,000$ billion, approximately twice as much debt as all the Third World countries put together with onetwelfth the number of people. 94

Most debtor countries in the South are currently at the mercy of a logic which has nothing to do with meeting basic needs

93 Ibid.

94 George, Susan (1985). op. cit. p. 102. 
or reducing the vulnerability of the poor. The IMF, as George has pointed out, exists to promote the growth and development of world trade. World trade, as discussed, can be expanded without net benefits accruing to poorer trading "partners". The IMF exists to ensure that trade and economic growth are maintained, whatever the social and environmental consequences. Countries were once considered to be in trouble when the average debt ratio exceeded 25 percent of their export earning, and this makes it absolutely clear just how much trouble they are in now that many countries in Africa have a debt ratio nearer to 35 percent. What is required is not a renegotiation of their debts, and a rescheduling of their indebtedness, but a completely new approach to the debt problem. Such an approach will need to address the vexed issue of national sovereignty and the operations of transnational corporations.

\section{Sovereignty and the multinationals}

During the last decade there has been mounting criticism of the role of transnational corporations (TNCs) in the "development" of the South. Most of this criticism has focused on the "irresponsibility" of TNCs which put profits before nature conservation and, for that matter, human livelihoods. Criticism tends to overlook the essentially rational and systematic way in which TNCs operate, usually with the support or complicity of national governments in Third World countries. It also overlooks 
the fact that TNCs act as self-contained systems, commissioning and utilizing technology, creating and exploiting consumer markets in the North, using "transfer pricing" to ensure that the benefits of peripheral development accrue to the center. The TNCs are the main beneficiaries of a free-trade/open-market system; they benefit from being able to sell expensively and buy cheaply, whether it is labor, primary products, services, or technology. ${ }^{95}$

There are also political advantages to be gained from commanding the process of resource-food conversion without necessarily having a major stake in the ownership of another country's resources. Nationalist sentiment was a potent force in persuading the Brazilian government to tighten its control over foreign-owned corporations in the development of the Amazon, although the model of "development" within which these corporations operated has still not been seriously challenged. 96 Indeed the state is frequently the guarantor of TNCs, not only by providing a legal basis for their operation, but by underwriting them financially. During the 1970s much of Latin America's agriculture became increasingly tied to high-technology inputs which received the bulk of state subsidies and preferential credits. In 1975 over half of Latin America's chemical fertilizers were imported. The interest of United States' companies in tractor

95 See Barnet, Richard and Ronald Müller (1974). Global Reach: The Power of the Multinational Corporation, Simon \& Schuster, New York.

96 Choucri, Nazli (1991). “The Global Environment and Multinational Corporations," Technology Review, April, vol. 23, no. 3, pp. 24-40. 
production was similarly important. The major thrust of agricultural policy in Latin America was to ensure that modern, commercial agriculture could be undertaken "competitively" through subsidized credit, fiscal concessions to importers and industrial suppliers. Guaranteed prices were paid to co-operating farmers and scarce public investment was allocated to large-scale physical infrastructure in areas like Northeast Brazil and Northwest Mexico, where heavily capitalized, irrigated agriculture was promoted. These policies met the demands of external agencies for "modernization" of agriculture, while providing opportunities for the realization of profits at critical stages in the production cycle. ${ }^{97}$

The increasing activities of TNCs in the South is thus the outcome of both a concern with their domestic profitability, and changes in the technology that TNCs employ. TNCs have themselves affected the international division of labor. Third World agricultural producers, notably in Latin America where agriculture has long been dominated by North American interests, have come to play a provisioning role within an evolving economic and technological system which has its origin and rationale in the North.

Another essential element in the way TNCs operate is their need to gain access to raw materials and labor. In their search to

97 Lopez Cordovez, L. (1982). "Trends and Recent Changes in the Latin American Food and Agriculture Situation," CEPAL Review, vol 16, United Nations Economic Commission for Latin America. 
find supplies of both, TNCs inevitably act in ways which are prejudicial to the economic and political sovereignty of national states. Agro-industrial operations in California and Mexico are a good example. In California, American companies own the land used in agribusiness operations and the capital to exploit it. They need to import the Mexican labor employed in the fields and the packing plants. In Mexico the land used by United States agribusiness is Mexican-owned, and the labor is freely available from the impoverished smallholder sector, but the capital has to be imported from the United States. The frontier is a flexible concept which corresponds more closely with geography than with the workings of agro-industry. TNCs increasingly make decisions that transcend their basis in legal ownership and materially affect nutrition, land tenure, and the environment. 98

By commanding the necessary technology TNCs can also ensure that there is an international division of labor in another sense. Not only do less developed countries provide most of the raw materials for industrial processing carried out in the North, but by employing peasant farmers on a contractual basis TNCs also enable the costs of maintaining the labor force to be passed on to poorer households. For most of these people employment by TNCs is on a casual basis. Whether they produce on their own land or work as seasonal laborers, they need other sources of livelihood

98 Schmidheiny, Stephan (1992). Changing Course: A global perspective on development and the environment, MIT Press, Cambridge, pp. 45-60. 
support, from the land or from urban employment. Many are being forced into making ever increasing demands on their environment by their dependence on the market. They resort to short-term unsustainable agronomic practices, shortening fallows, acquiring fertilizers on credit, removing tree and plant cover, reducing the range of crops within their "farming system." Others become ecological refugees, forsaking their homes for other areas where they can establish settlements. A substantial part of transnational migration from Haiti, the Sahel and Central America has environmental, as well as political, roots. 99

This underlines another effect of transnational penetration. Many of the consequences of agricultural intensification are directly attributable to agribusiness penetration. Agribusiness implies agricultural intensification, specialization in a few laboratory-bred crops and their treatment with chemical fertilizers. The problem is that even when the target of the production system (on-farm productivity) behaves as expected, other elements in the farmer's system are usually adversely affected (other crops, animals, other income-earning opportunities), while increasing intensification brings deterioration to elements outside the farming system (through pesticide use, land erosion and changes in diet, for example). TNCs, in making themselves more competitive, reduce the flexibility and

99 Choucri, Nazli (1991). op. cit. 
risk-avoidance which are essential to successful peasant agriculture.

Perhaps the most vivid example of transnational penetration is the destruction of the tropical rainforests. The statistics are appalling. In the last 25 years more than a quarter of Central America's rainforest has been turned to grass, and almost all the beef produced on it has gone to American hamburger chains. In 1960 the United States hardly imported beef at all. By 1981, 800,000 tons were being imported annually at a price less than half that obtained in the United States. As documented in the journal Environment: "the average domestic cat in the United States now consumes more beef than the average Central American."100 The 1970s was the decade in which one product received more development aid than any other in human history. The promotion of beef production in Latin America attracted over $\$ 10$ billion, at 1983 prices from the World Bank and the Inter American Development Bank. ${ }^{101}$

Elsewhere in the humid tropics the story has been much the same: large-scale finance for forest clearing and resettlement schemes, with the accent in Africa and Asia on timber production rather than ranching. In Indonesia it is planned to resettle four million people from Java, Bali and Lombok on the Outer Islands,

100 Nations, B. and L. Korner (1983). "Cattle Eat the Forest," Environment, vol. 25 , no. 2 , pp. $32-41$.

101 Ibid. 
which have little physical infrastructure and few support services. The human cost cannot be counted in full, since there is nobody but the settlers to count it. Those who have participated in such transmigration schemes have returned to speak about the experience in a tone not dissimilar to that of survivors from the holocaust. As demonstrated by the Brundtland Commission, transmigration is neither a substitute for redistributive land reform nor a viable solution to the over-population of Java.102

Tropical forests are destroyed primarily for economic reasons and, although it is important that there is growing awareness of the ecological problems produced, such awareness alone cannot be expected to turn the tide. Only radical changes in structural policies can do that. Earning foreign exchange, which is the primary objective, is not merely an objective of governments in the South, it is also the objective of their creditors, the IMF and the international banking community. The need to earn foreign exchange is compounded by the need to grow more food, and many countries are less exercised about what food is produced than that it is produced at all. The wilderness areas whose conservation even the World Bank now recognizes represent wasted, unproductive land to financially bankrupt governments in the South, intent on avoiding radical land reform at any price. The colonization of the tropical forest thus becomes a national goal, invested with the kind of symbolic importance which ecologically

102 WCED (1987). op. cit., p. 38. 
minded people reserve for endangered species. It is important to recognize these contradictions, painful though they are, for otherwise one cannot hope to enlist governments, international agencies and private individuals in sustainable tropical-forest utilization.

This chapter has argued that the structure of the international political economy is partly responsible for the worsening condition of local environments in many parts of the South. The pressure to achieve more economic growth, oriented to external demands in a period of indebtedness, to deepened the crisis afflicting the local economy in many rural areas. Instead of the sustainable development of their resources, especially those controlled by women, the strategies of survival forced upon rural households have led to overintensive cultivation, the depletion of capital stocks (including animals) and migratory patterns designed to increase cash income. Food production on the farm, which in Africa especially is often the province of women, has taken second place to short-term unsustainable strategies which serve to divest the farm household of entrepreneurial control. In the next chapter the question of sustainable agriculture will be addressed. 


\section{CHAPTER 4. SUSTAINABLE AGRICULTURE}

Despite an agricultural revolution in the South over the course of a single generation that has produced enormous benefits for farmers, consumers and economies, many of the poorest rural people are yet to benefit. They live in regions with poor-quality soils and unpredictable rainfall. Either they are remote from agricultural services that promote the package of inputs necessary to add value, or they cannot afford to take a risk by adopting the whole package. More importantly, many simply find the package unsuitable for their needs and tastes. In addition, inappropriate use of inputs imposes on others from agricultural pollution and environmental degradation.

If the projected world population of 8 to 13 billion people is to be fed, new efforts based on maximizing the use of renewable resources internal to the farm will be required. These will be centered on sustainable agricultural technologies capable of achieving permanent improvements to agricultural production that do not damage the environment.

\section{Overview of an Agricultural Revolution}

The success of the Green Revolution is simply explained. Agricultural scientists bred new varieties of staple cereals that: one, matured quickly, so permitting two or three crops to be grown each year; two, were day-length insensitive, so could be extended to farmers at a wide range of latitudes; and three, were 
producers of more grain at the expense of straw. These modern varieties were distributed to farmers together with high-cost inputs, including inorganic fertilizers, pesticides, machinery, credit and water regulation. These technical innovations were then implemented in the best-favored agro-climatic regions and for those classes of farmers with the best expectations for realizing the potential yield increases. ${ }^{103}$ As a result, average cereal yields have roughly doubled in twenty-five years. The remaining production growth has been met through a 20 percent expansion of the agricultural area.

Yet in many ways the most difficult challenges are just beginning. The world population is not thought likely to stabilize until there are between 8 and 13 billion people. Even at the lowest estimates, and given current inequitable access and rights to resources, there will be a need for agricultural production to increase substantially if adequate nutrition are to be maintained. Without very considerable growth the prospects for many people in the Third World are bleak. Given the extraordinary success of the Green Revolution, many believe that this model of development continues to provide the most effective and efficient prospect for all people of the South. However, not only have many people missed out on the benefits of this revolution. There have also been hidden costs.

103 Conway, Gordon and Barbier, Edward (1990). After the Green Revolution, Earthscan, New York, pp. 20. 


\section{Characteristics of inputs}

By focusing on the import to farms of new seeds or animal breeds, the Green Revolution has encouraged the development of two distinctly different types of agriculture in countries of the South. The first type has been able to respond to the technological packages, producing high-external input (HEI) systems of agriculture. 104 These tend to be endowed with good soils and adequate supply of water, through either stable rainfall or irrigation systems, and access to marketing infrastructure, modern farm inputs, machinery, transport, agroprocessing facilities and credit.

HEI systems are found in the large irrigated plains and deltas of South, South-east and East Asia, and parts of Latin America and North Africa. They tend to be focused upon monocrops and monoanimal enterprises, and geared for sale. So they include lowland irrigated rice, wheat and cotton; plantations of bananas, pineapples, palm oil, and sugar cane; market gardening near to urban centers; and intensive livestock rearing and ranching. 105

104 For a discussion on High and Low internal inputs see Francis, C.A. (1989). Internal Resources for Sustainable Agriculture, Sustainable Agriculture Programme Gatekeeper Series no. 8, International Institute for Environment and Development, London.

105 Wolf, Edward (1986). Beyond the Green Revolution: New Approaches for third world agriculture, Worldwatch Paper, no. 73, Worldwatch Institute, Washington, DC. 
The second type comprises all the remaining agricultural and livelihood systems which, in terms of area, are in the great majority. These are low-external input (LEI) systems and are located in drylands, wetlands, uplands, near-deserts, mountains, and hills. Farming systems in these areas are complex and diverse, and rural livelihoods are dependent on wild resources as well as agricultural produce. Agricultural yields are low, and the poorest countries tend to have higher proportions of these agricultural systems. ${ }^{106}$ Diversity means that what is appropriate for one farmer may not be for a neighbor; they are remote from markets and infrastructure; they are located on fragile or problem soils; and they have very low productivity.

The number of people of directly supported by LEI systems is enormous, probably some 1.4 billion. Yet "most agricultural development assistance...has emphasized external resources."107 They can neither afford to sustain the use of external resources, nor produce them in their own economies; the alternative lies in LEI systems, as for most poor countries no viable alternative exists. 108 The proportion of major crops currently planted to modern seed's varies widely across continents. Where HEI

106 Francis (1989). op cit., pp. 3-5.

107 OTA (Office of Technology Assessment) (1988). Enhancing Agriculture in Africa: A Role for US Development Assistance, US Government Printing Office, Washington, DC, p. 2.

108 Chambers, Robert, Pacey, A. and Thrupp, L. (1989). Farm First: Farmer Innovation and Agricultural Research, Intermediate Technology

Publications, London, pp. 15-28. 
systems occur, in almost every case external inputs have been substituted for the internal resources, rendering them less powerful. 109

The direct economic benefits of HEI systems are clear: more food per acre and per farm worker. Yet despite these returns, and considerable investment in research and extension, why have more farmers and countries not adopted HEI systems for agriculture?

\section{Farmer's views of modern varieties}

Using the conventional criterion of productivity, agricultural development judges HEI systems as successes. Yet farming households do not always see the modern varieties and associated package of external inputs in the same way as researchers. Their criteria for evaluating and making choices are frequently so different that the best products of research services are sometimes rejected, while others judged inappropriate are chosen by farmers as favorable.

In Colombia, a high-yielding variety of bush beans was rejected by farmers because the variable color made marketing difficult. Another variety rejected by researchers for its small bean size was acceptable because, as one farmer put it, "it is good for consumption purposes because it swells to a good size when

109 Lipton, Michael and Longhurst, R. (1989). New seeds and poor people, Unwin Hyman, New York, p. 40. 
cooked--it yields in the pot."110 In the Philippines, sweet potato varieties bred for high yield and sweet taste were rejected by upland farmers who preferred rapidly vining varieties that prevented weed growth and rain-induced soil erosion. They also selected varieties tolerant to weevil damage during the underground storage phase, as this meant the potatoes could be harvested only as required.111

Taste is one of the factors in the failure of modern corn seeds to be adopted widely. ${ }^{112}$ From the 1960s, agricultural research in Malawi has focused on dent varieties that have soft starch which is easier for modern rollers to handle to produce flour. But rural people prefer flint varieties for their taste and high starch content, and because they are less subject to insect damage during storage. Researchers accepted these drawbacks, but suggested that further new technologies would solve the problems. This would comprise the promotion of insecticides to control storage pests, and mechanical mills to overcome the difficulties of hand-milling dents. But the package was too costly and risky to farmers. By the beginning of the 1990s, only 5

110 Ashby, J.A., Quiros, C.A. and Rivera, Y.M. (1987). Farmer Participation in On-Farm Trials, Overseas Development Institute, London, p. 17.

111 Yapa, Lakshman (1993). "What are improved seeds? An Epistemology of the Green Revolution," Economic Geography, vol. 69, no. 3, pp. 254-273.

112 Barbier, Edward (1990). Malawi--Land Degradation in Agriculture Environment, International Institute for Environment and Development, London, p. 19. 
percent of the corn area was being planted to modern dent varieties. 113

\section{The Social Construction of Scarcity}

A common assumption of development theory is that people and places are poor because they lack resources: however, a reasonable case can be made that, in many instances, modern technologies have contributed to scarcity by destroying existing sources of supply and creating demands for new ones.114 Ecological relations of improved seeds provide an excellent example of this argument because they have replaced the sustainable reproductive capacity of local agriculture with the productive capacity of nonrenewable industrial inputs. 115

Over thousands of years farmers participated in the selection of improvement of seeds for food, fodder, and fiber. However, during the last 50 years a large industry has grown up around the sale of improved seeds; in the mid-1980s, it was a worldwide market of nearly $\$ 45$ billion. ${ }^{116}$ The capacity of seeds

\section{Ibid.}

114 In making this point, I do not in any way with to be misunderstood as making a Julian Simon-type of argument about unlimited resources and the planet's "vast growth potential." Simon, J. and Kahn, J. (1984). The resourceful earth, Blackwell, New York.

115 Shiva, Vandana (1991). The violence of the green revolution. Zed Books, London, pp. 24-41.

116 Doyle, J. (1986). Altered harvest: Agriculture, genetics, and the fate of the world's food supply, Penguin Books, New York, p. 33 
to naturally reproduced themselves had acted as a barrier to the entry of capital into developing improved seed, but techniques such as hybridization helped capital cross this threshold. Some have suggested that the very choice of this technique depended on its potential to transform seeds into a commodity. 117 For example, corn reproduces itself through both self and cross pollination. A variety of corn can be selected for particular traits, and by inbreeding it (self-pollination) over several generations a pure inbred line can be developed. The yield of such an inbred line is poor, however. Several decades ago, U.S. crop breeders discovered that a high-yielding hybrid corn can be obtained by crossing two pure inbred lines, due to a phenomenon known as heterosis or hybrid vigor. The commercially available hybrid seeds are produced by double-crossing two previous hybrids. Corn raised from hybrid seeds cannot be saved and used as seed for future planting because their yields are erratic and poor. This means that farmers have to purchase seed from seed companies every year. This is an example of the social construction of scarcity, a design built into the very development of hybrids. Of the techniques available for the general improvement of crop yield, hybridization was chosen partly for its capacity to suppress the key function of reproduction, thus creating a social scarcity

117 Kloppenburg, J.R. (1988). First the seed: The political economy of plant biotechnology 1492-2000, Cambridge University Press, New York, 114. 
that would be magnified later in the context of poor farmers in the third world. 118

Another aspect of scarcity is that improved seeds do not increase yields by themselves. To quote from Shiva:

The strategy of the Green Revolution...put new demands on scarce renewable resources and generated new demands for non-renewable resources. The Green Revolution technology requires heavy investment in fertilizers, pesticides, seed, water and energy. 119

Increasingly an important source of fertilizer nitrogen is that obtained from industrial fixation. In most fertilizer plants, hydrogen is obtained from methane in natural gas. Ammonia production is expensive in terms of energy-rich fossil fuels. The world production of nitrogen fertilizer rose from about 6.5 million metric tons in 1955 to 67.5 million metric tons in 1984.120 In 1984 developing countries accounted for more than 40 percent of the world's consumption of nitrogen fertilizer. ${ }^{121}$ The widespread use of chemical nitrogen also contributed indirectly to increasing scarcity by reducing the supply of naturally available organic nitrogen. It had the effect of underdeveloping knowledge of

118 See Conway and Barbier (1990). op. cit., p. 16.

119 Shiva, V. (1991). op. cit., p. 46.

120 Cox, G.W., and Atkins, M. D. (1979). Agricultural ecology: An analysis of world food production systems, W.H. Freeman, San Francisco, pp. 313-314.

121 Food and Agriculture Organization (1984). FAO fertilizer yearbook, FAO of the United Nations, New York, p. 51. 
biological sources of nitrogen related to crop rotation, multiple cropping, incorporation of nitrogen rich legumes in agricultural production, use of agricultural and plant remains, and application of animal manure. Azolla, a fern grown in association with rice paddy, is an important source of natural nitrogen. Other strategies for reducing the use of chemical nitrogen include the growing of plants that require less nitrogen or have a higher capacity for fixing nitrogen in root nodules. ${ }^{122}$

The widespread and growing use of chemical pesticides is another example of the social construction of resource scarcity. Pesticides cause the large-scale destruction of nontarget populations, the genetic evolution of pesticide-resistant organisms, the contamination of water and agricultural produce, the reduction of soil organisms, the reduction of soil organisms that maintain the quality of humus in the soil; moreover, they pose health risks to agricultural workers. Apart from what are very serious environmental hazards, chemicals are also expensive, their use has increased the dependence of third world farmers on international capital, and their continued use over time has increased the demand for these products. ${ }^{123}$

The pesticide industry -- that is, its research, development and marketing -- has had the effect of underdeveloping the emergence of alternative techniques. Which include: biological

122 Doyle, J. (1986). op. cit., p. 95.

123 Ibid. p. 120. 
control through prey-predator relationships; cultural methods, such as crop rotation, multiple cropping, and companion planting, that alter the environment by making it less suitable for pests; and crop breeding programs that develop disease resistant plants. Indeed, of all the techniques mentioned above those that have had the most support are the chemical ones, because they create the most exchange value. 124 Many of the alternative techniques mentioned, particularly the biological methods, work with natural cycles in the ecosystem by taking advantage of biological processes. They represent little cost to the user, but their development can be expensive because more sophisticated biocontrol requires much skill and funds. Even though more than 20,000 serious pest are known natural enemies are known for less than 10 percent. Entomologist Paul Debach posits that this research is underfunded because biological methods do not generate profits the way synthetic chemicals do. 125

\section{Concept of End-use Rational}

Another useful way to conceptualize the social origin of scarcity is to consider the end-use to which a technology is put. 126

124 Goodman, David and Redclift, Michael (1992). Refashioning Nature, Food, Ecology, and Culture, Routledge, New York, p. 37.

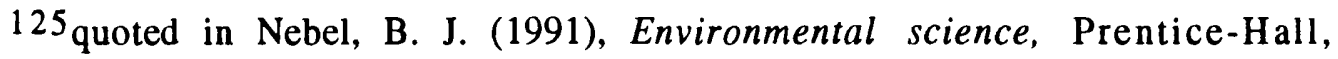
Englewood Cliffs, N.J., pp. 428-29.

126 Reid, Walter (1989). "Sustainable Development: Lessons from Success," Environment, vol. 31, no. 9, pp. 27-35. 
The concept of end-use rational involves the careful matching of resources and technology to particular uses so as to minimize waste of material and energy. To illustrate this idea, consider the energy required to produce nitrogen fertilizer: a pound of factory-produced nitrogen fertilizer requires about 19.700 thermal units of energy, while a pound of biological nitrogen obtained by plowing in a legume would use about 2,700 thermal units. 127 According to these figures, the expenditure of the extra 17,000 BTUs represents a saving unavailable with factoryproduced nitrogen -- creation of scarcity.

End-use logic has application in every area of technology: food, nutrition, agriculture, manufacturing, health care, housing construction, transportation, and education. In fact, the adoption of this principle in the context of SD gives new meaning to the terms resources, technology, and capital. End-use analysis begins with the needed use value and looks for the most direct way of satisfying it by using the minimum amounts of energy, material, and transport. This is called matching sources to end-uses. Thus the terms resources, technology, and capital have no universal meaning in the absence of a concrete end-use analysis of a given region. Indeed, the physical geography of region, its ecology, people's knowledge of plants and animals, are all part of the resource base. 128

127 Commoner, Barry (1977). The poverty of power:: energy and the economic crisis, Bantam Books, New York, p.156.

128 Goodman and Redclift (1992). op. cit.. pp. 4. 


\section{Building on Indigenous Knowledge}

In rural areas the livelihoods of poor households are diverse, commonly relying on a mix of agricultural produce, wild plants and animals, and trading. Over generations, people have developed a wealth of detailed knowledge about the quality and quantity of natural resources, and the means to manage and exploit them. This knowledge is a resource commonly neglected by agricultural projects, yet is critical to the success and improvement of low input systems. The first component of success requires taking the detailed local knowledge as a starting point and build upon it. Where agricultural development has done this, the economic benefits are remarkable. When development planning ignores this rule not only may goals not be met, but greater environmental and social damage may arise.

Provided groups or communities are involved in identification of technology needs, the design of testing and experimentation, the adaptation to their own conditions and finally the extension to other then sustainable and cheaper solutions can be found. Development focusing on appropriate ecological pest, nutrient and water management practices can lead to at least a 50 percent increase in the yields of crops, livestock and trees. 129

129 Ibid., p. 37. 


\section{Pest management strategies}

Agricultural pests are thought to destroy some 10-40 percent of the world's gross agricultural production. It is this potential for damage that has driven the search for synthetic pesticides and resulted in their widespread use. Pesticides, though, are not a perfect answer to controlling pests and pathogens. They can be dangerous to human health and damage natural resources and the environment. But more importantly to the farmer, pesticides are often inefficient at controlling pest. 130 They can cause pest resurgence by also killing off the natural enemies of the target pests. They can also produce new pests, by killing off the natural enemies of species which hitherto were not pest. Pests can become resistant to pesticides, so encouraging further applications; there are some 470 pest species known to be resistant to at least one product. ${ }^{131}$ Finally, pesticides provide no lasting control, and so, at best have to be repeatedly applied.

Integrated pest management (IPM) systems make use of the ecological processes of predation, competition and parasitism in six broad strategies of pest control:

- emphasizing natural enemies of pests and pathogens;

130 Conway, Gordon and Pretty, J. N. (1991). Unwelcome Harvest: agriculture and pollution, Earthscan, New York, p. 45.

131 National Research Council (1984). Pesticide resistance strategies and tactics for management, National Academy Press, Washington, DC p.4. 
- breeding crop plants or livestock for resistance to pests or pathogens;

- using locally available insecticidal compounds to reduce pests;

- increasing agricultural diversity to reduce pest or pathogens numbers;

- disrupting pest reproduction;

- the selective use of pesticides, with low toxicity and little environmental hazard. 132

IPM is the integrated use of these pest control strategies in a way that not only reduces pest populations to economically acceptable levels but is sustainable and non-polluting. It is by no means a new approach. Indigenous farmers have long used combinations of these technologies to provide a degree of pest control. All IPM successes begin by understanding local practices and ecological processes and building upon these. One traditional technique on citrus trees has been to encourage populations of predatory ants that feed on various insects pests. In China, bamboo bridges have for some 1,700 years been placed between branches to encourage movement of citrus ants from tree to tree, and whole orchards are colonized by securing a nest on one tree and then connecting this to others with the bamboo strips.133

132 Conway and Pretty (1991). op. cit.. p. 51.

133 Huang, H.T. and Pei Yang (1987). "Ancient culture of citrus ant as a biological agent," BioScience, vol. 37, pp. 665-71. 
Although IPM is a more complex process than scheduled spraying of pesticides, the large-scale IPM for rice programs in the Philippines, Indonesia and Thailand show that ordinary farmers are capable of rapidly acquiring the principles and approaches. This is producing a 50 percent reduction in insecticide use, a 10 percent increase in profits and a reduced variance of profits. The 50 percent reduction in pesticide use represents savings of $\$ 5$ to 10 million each to Thailand and the Philippines, and $\$ 50$ to 100 million to Indonesia. ${ }^{134}$

\section{Nutrient conservation strategies}

It is virtually impossible to maintain crop production without adding nutrients. When crops are harvested, nutrients are invariably removed and so have to be replaced. There are a variety of sources: the mobilization of existing nutrients in the soil and parent rocks; the fixing of nitrogen from the atmosphere; or the supply of organic or inorganic fertilizer. The options for nutrient conservation include improving the efficiency of fertilizers, using alternative sources of nutrients and environmental manipulation. ${ }^{135}$

134 Kenmore, P., Litsinger, J.A., Bandong, J.P., Santiago, A.C. and Salac, M.M. (1987). "Philippine rice farmers and insecticides: thirty years of growing dependency and new options for change," in Tait, E.J. and Napometh, B. (eds.) Management of Pests and Pesticides: farmers' perceptions and practices, Westview Press, New York, p. 38.

135 Nebel, B. J. (1991). op. cit., p. 420. 
The application of fertilizer, ideally, should closely match the needs of crops; but often farmers, for reasons of cost, will apply fertilizer only once. Fertilizer is often applied in excess of need, so some nutrients are lost from the farm as nitrates to surface or ground water, or as ammonia or nitrous oxide to the atmosphere. Efficiency of uptake is influenced by the crops themselves, the soil type and the timing and appropriate placement of fertilizers.

Farmers who can neither afford nor rely on a regular supply of inorganic fertilizers must find alternative organic sources of nutrients. Livestock manure's have been the traditional key to maintaining agricultural productivity in LEI systems, replenishing nutrients and improving soil structure. Composting is a technique of similar long standing that combines the use of animal manure's, green material and household wastes. The impact of legumes grown together with or before a cereal crop can further reduce and sometimes eliminate the need for nitrogen fertilizers. 136 Symbiotic bacteria present in specialized nodules that develop on the roots of the legumes can fix a considerable amount of nitrogen from the atmosphere. In well-nodulated and managed stand of legumes, fixation can double. The cultivation of cereals and legume crops together can improve both total yields and stability of production. Bushes and trees with nitrogen-fixing capacity

136 Ibid. 
also have beneficial effects on plants growing with or after them. 137

Nutrients are supplied when vegetation is incorporated in the soil as a green manure. This technique has been practiced for a long time; the Romans grew lupines and ploughed them in before sowing cereals more than 2,000 years ago. Quick-growing legumes are popular green manures. In Honduras, the introduction of the velvet bean as a green manure on poor soils has more than doubled corn yields. 138

Interventions that help to conserve soil and water are powerful techniques for nutrient conservation. Soil nutrients can be conserved by a wide range of physical structures of varying scale. Most of these are designed to check the surface flow of water, and thus perform the dual role of soil conservation and water harvesting and retention. If successful they can minimize the need for fertilizer application. The simplest approach is to construct earth bunds across the slope that act as a barrier to runoff. They are suitable on shallow slopes and are often used on tropical smallholdings together with contour planting. Sometimes the earth bunds are reinforced with vegetation such as crop stalks or trees. Such vegetative bunds are partly permeable, so crops planted in front of the bund also benefit from water runoff. More

137 Conway and Pretty (1991). op. cit., p. 70.

138 Bunch, Robert (1990), Low Input Soil Restoration in Honduras, Agriculture Program Gatekeeper Series no. 23, International Institute for Environment and Development, London, p.9. 
elaborate are various forms of retention and bench terraces, which raise crop yields by some 30-50 percent over those on nonterraces slopes. A lower-input alternative is to plant crops along contours. Water flow is slowed as it meets rows of plants growing perpendicular to the flow, thus improving infiltration. In strip cropping the main row crop is grown along the contour in wide strips alternating with strips of protective crop, such as grass or a legume. 139

These low-external input options for farmers comprise a wide range of interventions that will reduce the losses of nitrogen to the environment and act as alternatives to inorganic fertilizers. They are usually integrated on farms to give a finely tuned strategy specific to the physical and socio-economic conditions of individual farmers. As with IPM, integrated nutrient conservation successes have all begun with building on technologies that farmers are already using and with which they are already familiar.

\section{Building on local social organizations}

A common element of successful implementation of ecological sensitive agricultural technologies has been the attention paid to local social organizations. Success measured in the form of change sustained over long periods has been achieved

139 Nebel, B. J. (1991). op. cit., p. 436. 
through either building on existing patterns of organization, formal or informal, or the development of new institutions.

Yet this has not always been so in agricultural development. There have been two quite different approaches, both with the same goal of widespread adoption of changes. The first ignores existing local formal and informal institutions by dealing with individual farmers or households. These are chosen partly for their likelihood to adopt new technologies and are expected to induce further adoption in their community through a demonstration effect. At the other extreme is the approach of building community-wide co-operatives or collectives, whose action is governed by members and whose impact is expected to be positive on all members. 140

There is evidence to suggest that both approaches are flawed. At best only a few people benefit, and the gap between the poorest and the relatively wealthy grows. At worst the technologies are only adopted under the close supervision of external officials, the departure of whom often signifies the end of the effective use of the technology.

In the individual approach, the contract farmers are usually selected on the basis of literacy, wealth, readiness to change and progressiveness. This often sets them apart from the rest of the community. This approach is exemplified by the training and visit

140 Merchant, Carolyn (1992). Radical Ecology: The Search for a Livable World, Routledge, New York, p. 27. 
system of extension widely adopted in the South over the two decades.141 Extension agents receive regular training to enhance their technical skills, which they then pass on to farmers through regular contact with the selected contact farmers. This technical advice and knowledge are then supposed to diffuse from the contact farmers to all other farmers. The secondary transfer of the messages, though, has been much less successful than predicted, and adoption rates are commonly very low among noncontact farmers. ${ }^{142}$

Despite the intention of involving the whole community directly, the community or collective approach to extending technologies to rural people has also resulted in inequitable development, with benefits being captured by the relatively welloff. Large co-operatives, in which the needs of different members vary enormously and which are too large for widespread participation, have to be managed by small groups, usually comprising the most wealthy, to whom decision-making has been delegated. They are thus inevitably less effective in meeting the needs of the poor. 143

141 Morris, J. (1990). Extension Alternatives in Tropical Africa, Overseas Development Institute, London, p. 2.

142 Dover, Michael and Talbot, Lee (1987). To Feed the Earth: Agro-ecology for Sustainable Development, World Resources Institute, Washington, DC, p. 53.

143 Raeth, Paul (1993). Agricultural Policy and Sustainability: Case Studies from India, Chile, the Philippines, and the United States, World Resources Institute, Washington, DC, p. 8. 


\section{Small Entrepreneurial groups}

The alternative lies in the middle ground with small groups of households with a common interest in resource management and control. Sometimes these are existing formal or informal groups, such as traditional leadership structures, water users' groups, neighborhood groups, youth groups, and housing societies. On other occasions they are groups formed with outside facilitation to take charge of and manage a new resource, such as safer users' associations for irrigation, credit groups for loans access, or water-point committees to manage pumps. These groups promote incentives and enforce rules and penalties aimed at eliciting behavior conducive to rational and effective use of resources. 144

It is widely believed that taking social considerations into account results in greater costs. The concrete economic evidence, however, suggests quite the opposite. One study of twenty-five multilateral projects, conducted five to ten years after project completion, found the flow of benefits to have risen or remained constant were institutional development had been important.145

144 Uphoff, Norman (1990). "Paraprojects as New Modes of International Development Assistance," World Development, vol. 18, no. 11, pp. 1401-11.

145 Cernea, Michael (1987). "Farmer organizations and institution building for sustainable development," Regional Development Dialogue, pp. 1-19. (Published by the United Nations Center for Regional Development, New York) 
Where it had been ignored, economic rates of return declined markedly, and in some cases had become negative.

The benefits can have a wider social and environmental significance. Groups commonly pass through several phases. First the group establishes agreed rules for management and decisionmaking. These are then used by members as a vehicle to channel information or loans to individual members. As confidence grows with success, and resource bases expand, group activity evolves to an entrepreneurial stage where common action projects and programs are initiated.146

The next phase comprises inter-group co-operation as several groups might come together to federate and pool resources and knowledge. This opens up economies of scale that bring greater economic and ecological benefits. Lastly, the emergence of groups and federated groups makes it easier for government and NGOs to develop direct links with the poor.147 This results in greater empowerment of poor households, as they draw down on public services. It also permits more efficient passing of socially important messages relating to family planning, adult education, and sanitation.

146 Ibid., p. 4.

147 Bebbingtion, A. (1991). Farmer Organizations in Ecuador:

Contributions to Farmer First Research and Development, Sustainable Agriculture Programme Gatekeeper Series no. 26, International Institute for Environment and Development, London. 


\section{Policy frameworks to support sustainable agriculture}

The current policy frameworks of national governments all over the world strongly favor the HEI approach to agricultural development. Many countries are under multiple stresses from rising debt servicing requirements, and the declines in world commodity prices. These force debtor nations to take the shortterm view, and thus emphasize the expansion of export earnings and staple production, and the curbing of public expenditure. Yet increasing supply forces down world prices even further, a situation worsened by agricultural protectionism in the Northern trading blocs. 148

To overcome these pressing problems, policy makers tend to favor approaches for stimulating agricultural production that promise immediate returns, even if the long-term prospects are threatened. This means supporting large-scale enterprises, such as ranching operations plantations and large farms, through the subsidy of inputs, generous tax laws, selective extension of lowinterest credit and favorable product pricing. ${ }^{149}$ These incentives have helped boost production on more favorable lands, so spreading the adoption of Green Revolution technologies. But the long-term benefits of this strategy are not so clear. The costs incurred include resource degradation and increased inequity if agriculture expands into common property resources, if fertilizers

148 Reid, Walter (1989). op. cit., pp. 30-31.

149 Barbier, Edward (1989). op. cit., pp. 27-35. 
and pesticides are used inefficiently because of their low price, if food imports are favored at the expense of appropriate local foods and if particular commodities are supported at the expense of diverse and mixed farming. 150

LEI agriculture will not flourish beyond the small-scale successes documented above unless concerted action is taken both by national governments and by multilateral and bilateral development assistance agencies to adjust institutional, economic and legal frameworks to shift the balance of support towards LEI agricultural systems.

\section{Economic Development Scarcity}

Production is commonly defined as the creation of use values. But under certain circumstances production not only creates use values but also destroys them. Scarcity is a relation that grows out of the characteristic of production and appears in numerous aspects of development. The focus here has been on the concrete manifestation of this phenomenon in agricultural modernization within the relations of HEI systems. To restate the argument: The social construction of scarcity began with the genetic transformation of seeds into a nonreproducing commodity. The improved seeds were developed to respond to industrial inputs such as fertilizer, and pesticides. The creation of such demand creates scarcity by creating the need for these products.

150 Dover, Michael and Talbot, Lee (1987). op. cit., p.61. 
The continued use of inorganic fertilizer over a long period leads to the deterioration of soil structure and increased erosion, thus requiring larger quantities of fertilizer to simply maintain yields. The long-term use of chemical pesticides increases the demand not only for larger applications, but also for other, more powerful pesticides. The need for irrigation water to grow improved seeds creates a demand for the installation of infrastructure -- dams, canals, and wells -- and a demand for pumps, spare parts, and fuel.151 Since these inputs are purchased in the market, obviously some classes of society will experience scarcity more severely than others. In very arid areas irrigation creates an added burden through salinization, leading to the loss of cultivable land. Good land can also be lost to waterlogging caused by irrigationinduced raising water tables. In agricultural modernization the loss of knowledge of sustainable practices due to the devaluation of traditional indigenous knowledge (LEI) can cause decreased yields. The newer varieties of corn, wheat, and rice yield lower quantities of biomass for organic residue and animal fodder, depriving the soils of important sources of natural organic nutrients. 152

Agricultural modernization through use of improved seeds was a model of scientific agriculture. At one end of this model were the crop breeding centers and gene banks, and at the other

151 Yapa, Lakshman (1993), op. cit., p. 269.

152 Ibid., p. 270. 
were the large agricultural universities and extension services -- a system of science and technology that uses large amounts of scarce financial resources and creates extreme dependency. Furthermore, this model was instrumental in conferring more power to expert scientists, consultants, bankers, and agents of agribusiness, a shift that was justified in the name of increased food production to meet the urgent needs of the growing hungry masses. The real food needs of poor people served the ideological needs of the promoters of the model of improved seeds quite well by helping to marginalize the critics of HEI.153

This chapter was partly an exercise in understanding how problems are identified and solutions are proposed. Since hunger and malnutrition are problems, the Green Revolution of improved seeds was adopted as the solution. But such solutions are in fact part of the problem, because poverty is a form of scarcity induced by the very process of development. The argument was illustrated by examining HEI and LEI systems. Clearly, there is a need for more analysis to prove the connection between development and scarcity.

The experience explored, in this chapter, suggests that agricultural production in LEI systems can improve yields through sustainable methods, accompanied by further indirect economic benefits. Other, benefits are to preserve locally valued cultural 
sites and globally valued biodiversity and ecosystems, both of which are threatened by HEI. 


\section{CHAPTER 5. SUSTAINABLE RESOURCE MANAGEMENT}

Previous chapters have discussed what is happening to the environment in Third World countries, and the kinds of structural processes within the international economy which have alter the relationship between the Northern and Southern hemispheres.

In discussing sustainable agriculture it was necessary to examine HEI and LEI within the context of peoples' choices and interests, as well as ecological principles. In this chapter the argument turns to the principles and methods of environmental management. When one considers the principles and methods of environmental management as practiced in the Third World, it is evident that most types of intervention are neither particularly effective nor grounded in an objective scientific approach.

Further, this chapter looks at the market failures and government policies that are at the center of many environmental degradation problems facing the third world. Environmental management is usually a responsive set of techniques rather than a framework for implementing policy. It also becomes clear that what is meant by environmental management often ignores or devalues the experience of poor people in the South, those who are usually closest to the problems. Often solutions are imported from the experience of developed countries, using methodologies which are of little relevance to different circumstances. To begin to achieve success at implementing workable environmental policies in the 
South one seems to require that first unlearn much of what one knows about conservation and the environment in the South.

The premise of UNCED (the Earth Summit) was that global environmental management can work. The project, as it emerged out of Rio, has three principal approaches-- a growing body of international environmental treaties among nation-states, increased foreign aid for environmental protection and management, and supposed poverty alleviation, channeled and managed mainly through the global environmental facility (GEF) and other financing arms of the World Bank. The vision is that investigators and officials can efficiently gather information, starting with countless local ecosystems and communities, and devise plans, programs, and rules at the local, national, and international level to administer and manage the biosphere.154 The nation-state is the basic unit in such a system of global environmental management, though key powers at the global level are devolved to bureaucracies with universal responsibilities, such as the World Bank. In short, global environmental management assumes, to summarize an analysis published in The Ecologist, assumes universally applicable knowledge, effective global enforcement, and a world political culture in which such knowledge and enforcement would be grounded.155 I will examine these assumptions in turn.

\footnotetext{
154 Whose Common Future? Reclaiming the Commons (1993). Written by The Ecologist, Earthscan, London, pp. 5-6.

155 "Global Management," (1992). Ecologist, vol. 24, no. 4, pp. 180-2.
} 
The first question cannot be neatly separated from the structures of politics and governance in which it is embedded. The growing revolt of local knowledge against the generalized, universal development schemes of the World Bank is a leading example. ${ }^{156}$ Surely, if decades of failed international development efforts have taught anything, it is the folly of induced, uniform HEI projects. Such schemes ignore and often destroy the local knowledge and social organization on which sound stewardship of ecosystems as well as equitable economic development depend. The most important elements of local knowledge are lost when attempts are made to abstract and generalize them to a national or global level-- if the attempt is made at all. This knowledge cannot be separated from he place in which it is used and continually evolving; nor can local people's customs, methods, and skills be artificially reconstructed through such efforts. ${ }^{157}$

A typical example is muang phai, the watershed conservation measures and water-channel maintenance practice of village groups in Thailand. Foreign aid assisted the government irrigation authority to build new, more expensive dams and

156 For examples in Africa see, Onimode, Bade (ed.) The IMF, The World Bank and The African Debt: The Social \& Political Impact, Zed Books, London.

157 Ghai, Dharam and Vivian, Jessica (1993). Grassroots Environmental Action: People's Participation in Sustainable Development, Routledge, New York, pp. 34-40. 
channels, with little attention to local knowledge and practices. Control of the modernized infrastructure was vested in the government irrigation authority. Not unexpectedly, the new systems encountered unforeseen ecological and maintenance problems, since the alleged beneficiaries, local farmers, had been effectively dispossessed by the enclosure of the natural resources over which they once had real control. Attempts by the government irrigation authority, on the recommendation of foreign development experts, to set up new water users' associations among the farmers failed. ${ }^{158}$ There is ample documentation of analogous problems in many other areas of resource management, such as afforestation. The conclusions of an Indian forestry official, describing the ruin of a World Bank reforestation project in the Himalayas which depended on the involvement of local villages, are pertinent: "these solutions do not require much money, but they require attention to details, commitment. That is what is lacking. What we have learned is that you cannot throw money at these problems."159

158 The discussion of muang phai irrigation is based on the following sources: Lohman, Larry (1991). "Who Defends Biological Diversity?" Ecologist, vol. 21, no. 1, pp. 5-13; and Tangwisuttijit, Nantiya (1991). "Arguments that hold water," Nation, October 5, pp. C1-C3.

159 Coll, Steve (1992). "A plan to save the globe dies in a village," Washington Post, May 24, A1. In an article written in anticipation of the Earth Summit, Coll describes the collapse of a World Bank reforestation project in a small Indian village, Chopta. He views it as a troubling portent for the Earth Summit, which will called for more funding of similar projects. He cites interviews with villagers who contend that Indian government officials and World Bank staff never even visited the village, let alone tried to ascertain their needs. 
The whole mode of global policy discourse that has become popular is so general as to be irrelevant to many real political and social challenges The key insight that such discourse misses is the extraordinary and irreducible connection of the biosphere at all levels. The diversity of local and regional ecosystems is the direct evolutionary and historical underpinning of the remarkable social and cultural diversity of human communities and societies. Effective social and political action has to be based at the appropriate level in terms of specific elements and constraints. 160 Events that have great global environmental and social repercussions may start from local incidents which at the time are indistinguishable from others. Over the late 1970s and 1980s, more than a thousand social activists were murdered in obscurity in the Brazilian Amazon, a number of them rubber tappers fighting for the protection of the rainforest. The assassination of their leader in December 1988, Chico Mendes, and the immediate, intensive efforts of a handful of environmental activists in Brazil and the United States to ensure that the lifework of Mendes would not be forgotten led to, an unprecedented outpouring of international concern. The social and ecological crisis in the Brazilian Amazon because an issue the Brazilian government could no longer ignore. The uproar over his death was also a factor

160 Adams, William (1991). Green Development: Environment and Sustainability in the Third World, Routledge, New York, pp. 83-86. 
leading to the delay of World Bank loans, and the Brazilian government's subsequent lobbying to host the UNCED.161

The example of Mendes and the Brazilian rubber tappers aptly confirms that successful environmental management has to operate through the very social groups which are being marginalized by the development process. Attempts to manage the environment internationally through designated "biosphere reserves" in vulnerable areas and international agreements to restrict access to the commons, have proved largely unsuccessful. 162

The impotence of many existing international environmental treaties further confirms Redclift's observations, and gives little ground for confidence in the effectiveness of many future conventions if nothing else changes. Most environmental treaties have no effective provisions for enforcement, and few data are collected on compliance. ${ }^{163}$ Norway is a country that ranks near or at the top for its domestic and international environmental commitment. And yet a survey conducted by a Norwegian NGO,

161 Ekins, Paul (1992). op. cit., pp. 83, 146.

162 Durning, Alan (1989). "Action at the Grassroots: Fighting Poverty and Environmental Decline." Worldwatch Paper 88, Worldwatch Institute, Washington, DC., p. 18.

163 French, Hilary (1992). "After the Earth Summit: The Future of Environmental Governance," Worldwatch Paper 107, Worldwatch, Washington, p. 28; see also Birnie, Patricia (1992). "International Environmental Law: Its Adequacy for Present and Future Needs, " in Hurrell, Andrew and Kingsbury, Benedict, eds (1992). The International Politics of the environment: actors, interests, and institutions, Oxford University Press, New York, pp. 70-78. 
Bellona, concludes that Norway is probably failing to comply with twelve of twenty-seven international environmental agreements it has signed.164

One of the main functions of the United Nations Environmental Program (UNEP) since its founding in 1972 has been to promote international agreements. Prior to the signing of the Montreal Protocol (1987) to regulate emissions of ozonedestroying CFCs, UNEP's crowning achievement was its Mediterranean Action Plan (1975), the most successful by far of ten action plans to clean up the world's seas by region. The highlight of the plan is the Barcelona Convention (1978), in which all eighteen Mediterranean states agreed to take drastic actions to reduce and purify sewage and chemical waste effluents in coastal areas. 165

Although the Mediterranean Action Plan was a great diplomatic success -- it brought Albania, Libya, and Israel to the same negotiating table to agree on environmental collaboration -it is an environmental failure. The Mediterranean is becoming a dead sea. After huge expenditures, only 30 percent of the Mediterranean's sewage receives any treatment whatsoever. 166

164 French, Hilary (1992), op. cit., p. 28.

165 Haas, Peter (1990). Saving the Mediterranean: The Politics of International Environmental Cooperation, Columbia University Press, New York, p. 9.

166 Hinrichsen, Don (1991). review of Saving the Mediterranean: The Politics of International Environmental Cooperation, by Peter Haas, International Environmental Affairs, vol. 3, no. 3, p. 235. 
In flagrant violation of other international conventions supposed to regulate discharge of petroleum at sea, vessels release 650,000 tons of oil and other hydrocarbons annually in the Mediterranean, the equivalent of seventeen Exxon Valdez oil spills every twelve months. 167

The most optimistic assessments of environmental effectiveness of the Mediterranean Action Plan claim that overall water quality has not gotten any worse since its inception in 1975 , something of an accomplishment since population and production have increased in the Mediterranean region during the same period. According to Peter Haas, even these modest claims are anecdotal since "no synoptic data are available on Mediterranean water quality, nor are there time series data." 168

Optimists concerning the effectiveness of international environmental treaties cite the Montreal Protocol mentioned above. Signed, 1987, it is an almost unqualified diplomatic and technical success: in 1990, the industrialized and developing countries revised it and agreed on the total phase-out of production of ozone-destroying CFCs (e.g. halons, methyl chloroform, and carbon chloride) by 2000 . Unfortunately, to come to terms with many global environmental problems, diplomatic successes and technical breakthroughs alone may be largely irrelevant by the time they occur. The balance of the biosphere

167 Haas, Peter (1990). op. cit. p. 130-131.

168 Ibid. 
does not always respond on command even when, such as the phasing out of CFCs, the world's nations become sufficiently concerned to agree on something and carry it out. The very thing that prompted unprecedented international action, the long-term persistence of ozone-destroying CFCs in the atmosphere once they are released, means that the ozone hole may continue to grow for years and perhaps decades after production and use of CFCs ceases. Moreover, as a National Academy of Sciences study on global environmental change warns,

there is no guarantee that the chemicals developed as substitutes for CFCs will prove benign in the long run (CFCs themselves were thought to have ideal properties when they were introduced in the 1930s). Hydrochlorofluorocarbons (HCFCs) and hydrohalocarbons (HFCs), prominent among the candidates to be used as substitutes for CFCs, have already provoked opposition from those concerned about their potential contribution to the greenhouse effect. 169

The same study warns against taking the Montreal Protocol as a precedent for dealing with global environmental change. The Montreal Protocol requires no real changes in national and global economic and social behavior; it phases out one technical fix and replaces it with another, which, it is hoped, will prove environmentally more benign. Truly addressing other global environmental problems-- tropical deforestation and climate

169 Morrisette, Peter and Plantinga, Andrew (1991). "Global Warming: A Policy Review," Policy Studies Journal, vol. 19, no. 2, pp. 163-172. 
change, for example-- may require changes of historical dimensions, involving millions or even hundreds of millions of responsible actors, and poses thorny questions of equity within nations and among them.170

Centralized, environmental management fails at the national level, too, in most third world countries. Costa Rica is a particularly illuminating example since it has often been cited as a model, for having set aside and protected a larger proportion of its forests and other natural areas than the United States. Costa Rica has benefited from a more intense level of international environmental assistance than almost any other country, through project oriented NGOs like the World Wildlife Fund and a variety of other agencies. It is also, the beneficiary of one of the largest "debt for nature" swaps. Indeed, partially because of this international attention, an oversized environmental bureaucracy has proliferated in Costa Rica over the past fifteen years. A 1988 study identified twenty-seven "sections, divisions, units, juntas, institutes, and councils often working at cross purposes and almost never acting in cooperation with each other, charged with implementing one or another aspect of environmental policy."171 The country has over 1,500 different environmental laws and

170 Ibid.

171 Carriere, Jean (1991). "The Crisis in Costa Rica: An Ecological Perspective," in Goodman, David and Redclift, Michael, eds., Environment and Development in Latin America: The Politics of Sustainability, Manchester University Press, Manchester, England, p.194. 
decrees in force, many of them incompatible with one another, something that is not the problem it appears, since few laws are enforced. 172

In recent years, Costa Rica has had one of the highest rates of deforestation of any nation on earth, averaging 4 percent annually for much of the 1980s.173 By 1985, 25 percent of the area of the country's legally protected forest reserves had been cleared, and many of the country's famed national parks were threatened or already partly deforested.174 Most of the deforestation has proceeded through a cycle that starts with logging, followed by occupation for three to five years by landless farmers, and finally conversion into cattle pastures. The deeper causes are structural ones that post-UNCED solutions of global environmental management, such as the biodiversity convention and more aid for environmental projects, could hardly begin to address, highly unequal land tenure coupled with typical macroeconomic crisis linked to the country's declining earning from commodity exports and the increasing burden of its foreign debt.

By the mid-1980s, Costa Rica had the highest per capita foreign debt in the Third World; $\$ 1,500$ for every inhabitant of the country. Forty percent of Costa Rica's foreign exchange

172 Ibid., p. 195.

173 World Resources Institute, World Resources 1990-1991, p. 102.

174 Carriere (1991). op. cit., p. 195. 
earning was going to service this debt, and tree-quarters of all the new foreign loans the country received simply went to help pay it back. 175 The country was obliged to follow the conditions of a typical World Bank/IMF adjustment program, resulting in disproportionate budget cuts for the National Parks Service and the Forestry Directorate, as well increased economic pressures on the poorer, landless members of the population to migrate into still unoccupied forest lands and protected areas. 176 A plausible case can be made that the adverse environmental effects of the World Bank sponsored adjustment program far exceed in scale and magnitude whatever marginal environmental benefits the country might obtain from a few million dollars for discrete environmental projects it might receive from an expanded global environment facility.

\section{Indigenous environmental management}

It would be inaccurate to assume that environmental management is the sole prerogative of technically trained people from developed countries. Many rural people using simple technologies in the Third World possess a fund of information about their environment in ways that are sustainable in the long term. However, the experience and knowledge of such people is only rarely incorporated in the formal structure of rural

175 Ibid., pp. 192-193.

176 Ibid. 
environmental planning in developing countries. In the previous section some of the limitations of the kind of environmental management of the North were identified. It is now necessary to ask, What are the implications of seeking to learn from indigenous experiences of managing the environment for the development of rural societies in the South?

First, it is clear that among indigenous people (tribal or "native" peoples) of Third World countries, sustainable practices are adhered to because traditionally they were the only guarantee of survival. It is one of stewardship, particularly in societies where the use of natural resources were not necessarily tied to their ownership. Ovington and Fox explain:

In the case of the Australian Aboriginals, identification (with their environment) after two or three thousand human generation is so complete that they do not separate themselves from their environment. They use themselves as part of the landscape, not apart from it...Once people are taken out of close contact with the natural environment which sustains them, the perception of dependence fades. The notion that the ultimate source of food, shelter, new crops, new drugs and new materials must ultimately come from the Earth loved forces in this change of perception. 177

Not all human groups live as closely or as symbiotically with their environment as the Australian Aboriginals, but the recognition that people depend upon their environment for their survival is widespread. A particular cultural group will not necessarily

177 Ovington, J. and Fox, A. (1980). Wilderness - A Natural Asset, Cambridge University Press, Cambridge, p. 58. 
respect the constraints on resource use stemming from the theoretical carrying capacity of land, but the knowledge gained from sustainable resource use forms part of the environmental practices of most indigenous populations. People are used to interfering and modifying their own management practices and have grown used to living with the consequences of their action. It is much more difficult to predict, or justify, interference in culturally rooted practices in the interest of management strategies that are imposed from outside. As Nowicki puts it: "...there is a difference in making a punctual investment which increases the overall productive capacity of an ecological system which supports itself, and the investment which changes initial circumstances so that the system is no longer self-supporting." 178

It should be remembered that, within most indigenous groups whose livelihoods are not dependent on commodity production for the market, there is no internal tendency towards the maximization of profits or the creation of an economic surplus. The more intensive use of traditional techniques is linked to a strategy for minimizing risks and widening options in the face of the insistent process of capital accumulation. In the course of development indigenous environmental knowledge is often lost, because it becomes less relevant to the new situation and because

178 Nowicki , P. (1985). "Cultural Ecology and Management of Natural Resources or Knowing When Not to Meddle," in McNeely, J. and Pitt, D., Culture and Conservation: The Human Dimension in Environmental Planing, p. 285. 
it is systematically devalued by the process of specialization around competitive production for the market.179

Traditional environmental knowledge is not only devalued by development institutions, it is also largely overlooked in the environmental management literature, as Norgaard documents. 180 This is partly because of the way such knowledge is recorded in the cultures of native peoples. Without knowledge of the culture a people possess one is unlikely to be aware of their knowledge of their environment. The corollary is that, if we want to know how ecological practices can be designed which are more compatible with social systems, you need to embrace the insight of indigenous people, including their ways of organizing their knowledge of their environment. However, Norgaard argues, traditional knowledge is location specific and only arrived at "through a unique coevolution between specific social and ecological systems."181

Indigenous people "see" nature differently, precisely because their practices acknowledge its centrality. Studies in ethnobotany reveal that people in societies characterized by simple technologies are aware of differences in nature which are invisible to specialists from outside. Dandler and Sage, for example, report that in one Aymara community in the Bolivian Altiplano five peasant households named 38 sweet and 9 bitter

179 Ibid., p. 286.

180 Norgaard, Richard (1989). op. cit., p. 607.

181 Ibid., p. 609. 
varieties of potato that they themselves cultivate. ${ }^{182}$ They are aware also that each variety possesses advantages and disadvantages as part of a strategy for minimizing risks. Their interest in maintaining crop diversity is based not on belief in diversity for its own sake, but on the knowledge that diversity reduces their environmental vulnerability.

Their knowledge is based on the production of use values and the adaptation of their agricultural practices to ecological conditions. Indigenous technical knowledge informs these practices, in conserving energy, in cultivating crops, in combination with animal rearing, and in other farming/conservation techniques.

The use of indigenous knowledge is linked to the strategies which the culture has devised for coping with risks. These microlevel practices protect against attack from pests and genetic erosion, through maintaining diversity, in the ecological system, in crops and in genetic materials. The components of these strategies allow a sustainable system to be reproduced in which biological nutrients are conserved, and food consumption meets different nutritional needs. At the same time the labor effort expended in production and consumption is spread over the agricultural calendar. Another important factor is that these strategies reduce fluctuations due to seasonality, both in the

182 Dandler , J. and Sage, C. (1985). "What is Happening to Andean Potatoes? A View from the Grassroots," World Development, vol. 13, no. 3 pp. 364-371. 
habitat and in seasonal vulnerability to disease. Finally, access to commonly held resources is linked to the investment which a household makes in the community. The strategies adopted do not necessarily succeed in ensuring adequate livelihoods, but they are designed to reduce the risks to those livelihoods. ${ }^{183}$

To appreciate the potential gains in widening our view of environmental management one needs to be aware not only of differing epistemological positions, but even of different cosmologies. Incorporating the environment into development planning implies incorporating cultures and cultural perspectives. The problem of how to manage the environment effectively in the Third World is usually raised in terms of their cultural adaptations to development processes. Perhaps the more urgent question is whether "we" are prepared for the cultural adaptation that is required of us. The reference to cosmologies was deliberate, since the view that people take of their environment is intimately linked to their conception of their own place in space and time. A collection edited by McNeely and Pitt provides evidence that people in small-scale societies, the tribal or indigenous people who make up 200 million of the world's population, often view the environment within a long-term time horizon, like many ecologists. ${ }^{184}$ In pastoral societies, for

183 Burkey, Stan (1993). People First: A Guide to Self-reliant, Participatory Rural Development, Zed Books, New Jersey, p. 34.

${ }^{184}$ McNeely, Jeffrey and Pitt, David eds. (1985). Culture and Conservation: The Human Dimension in Environmental Planing, Croom Helm, London. 
example, significant events may be separated by decades. The inability to appreciate this fact helps explain why, when people judge environmental losses to have become critical, development personnel are often the last to know. It is essential to know when environmental problems are unsustainable, to people as well as in technical terms, and the answers lie partly in cultural interpretations of "crisis." 185

\section{Environmental movements and the South}

It is sometimes argued that social movements in developing countries are unlikely to embrace environmental demands, since the contradictions of the development process leave poor people with little option but to make ever increasing demands on their resource base. By the end of the Earth Summit, many participants and journalists were articulating a simple equation to explain complex relationship between environment and development: poverty causes environmental degradation. ${ }^{186}$ They saw developing countries and poor people as fixated on survival and basic development issues, and if exploitation of natural resources contributed to those goals, so be it.

The growth of new urban environmental movements in the Third World demonstrates that such an argument can be

185 Ekins, Paul (1992). op. cit. pp. 4-12.

186 Broad, Robin and Cavanagh, John (1993). "Beyond the Myths of Rio," World Policy Journal, vol. 10, no. 1, pp. 65-73. 
challenged. The growth of new urban social movements in Latin America, for example, clearly owes something to environmental consciousness. 187 The role of ecological considerations in rural social movements in the South is certainly ambiguous, but those who constitute the movement are engaged in a livelihood struggle, and they recognize that this livelihood struggle can be successful only if the environment is managed in a sustainable way. As nature is transformed under capitalist development and natural resources are created, social struggles are initiated which resist the incorporation of nature in wider spheres of accumulation. The concern of these movements with the distribution of resources is usually linked to ideas about the alternative uses to which they could be put. The struggle to create the condition of existence necessary for social and biological reproduction, outside the spheres of capitalist accumulation and market-oriented resource use, is a struggle to effect profound environmental objectives. ${ }^{188}$ I will examine one of the more known social movements in the South.

The green belt movement in Kenya

187 See for example, Slater, D. (1985). New Social Movements and the State in Latin America, Blackwell, London.

188 Samatar, Abdi (1993). "Structural Adjustment as Development Strategy? Bananas, Boom, and Poverty in Somalia," Economic Geography, vol. 69, no. 1, pp. $25-43$. 
Support for mass tree planting by Kenyan women began in June 1977 on the occasion of World Environment Day. The activity was co-ordinated by the National Council of Kenyan Women and developed into a program "that approached the issues of development holistically and endeavored to build on local expertise and capabilities." 189 One of the leading figures in the movement, Wangari Maathai, has described the genesis of the movement in the action which the Women's Committee took together with a small group of very poor rural women. ${ }^{190}$ The initial steps toward forming a movement were taken by Kenyan women outside the communities; they identified forest losses as among the most serious causes of soil erosion and land degradation in Kenya. The Green Belt movement has grown slowly but surely around a program of reforestation, environmental awareness and better livestock and crop production. 191

Once contact has been made with community members who wish to participate in the movement, they are urged to apply to headquarters indicating whether they wish to participate by growing tree seedlings or by planting them. The participants then carry out certain work before they can receive trees, preparing

189 Maathai, Wangari (1986). The Green Belt Movement: Building Block for Sustainable Development, Overseas Development Institute, London, p.20.

190 Ibid., p. 25.

191 Ekins, Paul (1992). op. cit. p. 151. 
the ground for tree nurseries or digging holes for planting. This work is checked by the Green Belt movement field staff.

Participants in the program then attend meetings to teach them forestry techniques, while seedlings are being produced the community is being persuaded to plant trees. When the seedlings are ready they are distributed to members of the community. In this way over 1000 public green belts, each with over one thousand trees, have been planted and another 15,000 private green belts, under the management of small farmers, are registered with the movement. 192

Since about 90 percent of Kenya's 19 million people live in the rural areas and most of them use fuelwood, the demand for timber is unlikely to decline. Similarly in urban areas wood is converted to charcoal for domestic use. In many parts of the country soil fertility has fallen and famine has become a recurrent phenomenon. This loss of soil fertility is connected with the indiscriminate felling of trees and the gradual encroachment on forests by human and livestock populations. Forests cover about 2 percent of the land formerly forested, and over two-thirds of Kenya's land area is arid, semi-arid or desert land. Maathai argues that tea and coffee plantations should not be developed while so much lost land has still not been reclaimed.193

192 Ibid.

193 Maathai (1986). op. cit., p. 16. 
The environmental movement has been discussed in the context of wider social struggles to retain control over the natural environment, often in the face of opposition from development agencies and governments. It is clear from the case discussed that there are two essential characteristics of environmental movements in the Third World: supported by the people engaged in a livelihood struggle, and struggle linked to sustainable objectives. Where poor peoples' livelihoods are at stake, environmental movements will incorporate conservation objectives within the context of basic needs.

This chapter has argued that environmental management must make use of social movements dedicated to environmental ends. It must also make use of the knowledge and experience which people possess about their environments. The next chapter will examine sustainability, for the technical limits of sustainability are not fixed. What people can achieve for themselves is partly governed by these limits. 


\section{CHAPTER 6. THE LIMITS OF SUSTAINABILITY}

Earlier chapters have looked at how the environmental consequences of development have posed a contradiction. As the environment has become internationalized it has been transformed, and social struggles have mounted for the control and ownership of natural resources. The attempt to import solutions to environmental problems from the North, in the form of growth, therefore assumes more importance as the ecological crisis of development deepens. In this chapter the discussion steps back and examines the theoretical importance of sustainability. Particularly, I concentrate on the contradiction of growth and sustainability.

\section{The concept}

The concept of sustainability originated in the discussions of renewable resources such as forests or fisheries, and has subsequently been adopted as a broad slogan by the environmental movement. 194 Most proponents of sustainability therefore take it to mean "the existence of the ecological conditions necessary to support human life at a specified level of

194 Peet, John (1992). Energy and the Ecological Economics of Sustainability, Island Press, Washington, DC., pp. 21. 
well-being through future generations," what has been called ecological sustainability. 195

Since ecological sustainability emphasizes the constraints and opportunities that nature presents to human activities, ecologists and physical scientists frequently dominate its discussion. But what they actually focus on are the ecological conditions for ecological sustainability -- the biophysical "laws" or patterns that determine environmental responses to human activities and humans' ability to use the environment. This is the basis of one of the major contributions of sustainability -- the realization that in addition to or in conjunction with the ecological conditions, there are social conditions that influence the ecological sustainability or unsustainability of the people-nature interaction. For example, one could say that soil erosion which undermines the agricultural basis for human society is a case of ecological (un)sustainability. It could be caused by farming on marginal lands without adequate soil conservation measures-- the ecological cause. But the phenomenon of marginalization of peasants may have social roots, which would then be the social cause of ecological unsustainability.

Emerging from a broad review of the uses of sustainability are several general perspectives, or contexts, in which the term is used. A social definition of sustainability might include the

195 Brown, Becky, Hanson, M., Liverman, D. and Merideth, R. (1987). "Global Sustainability: Toward Definition," Environmental Management, vol. 11 , no. 6, p. 714 . 
continued satisfaction of basic human needs--food, water, shelter- as well as higher-level social and cultural necessities such as security, freedom, education, employment, and recreation. 196 The social perspective is often more concerned with individuals than with nations or species. Hence, socially defined sustainability might specify the survival and happiness of the maximum needs to even the poorest groups. On the other hand, some feel that it is against the long-term social good to aim at sustaining everyone because certain social groups are too weak or are unwilling to control their populations. 197

Perhaps the most comprehensive and detailed portrait of the contours of sustainability has been offered by Lester Brown.198 Setting his conception of sustainability against the backdrop of destructive and burdensome trends emanating from industrialization and economic modernization, Brown defines the sustainable society in terms of population stabilization, the preservation of the earth's renewable natural resource base, prudent use of land (urban, farm and wilderness), the protection of biological systems (including fisheries, grasslands and forests), the reforestation of the earth, the maintenance of the web of life

196 Maslow, A.H. (1970). Motivation and Personality, 2nd edn. Harper and Row, New York, p.46.

197 Hardin, Garrett, and J. Baden (1977). Managing the Commons, W.H. Freeman, San Francisco: CA, p. 13.

198 Brown, Lester (1981). Building the Sustainable Society, W.W. Norton and Company, NY. 
from microorganisms to the gene pool to extant species and flora and fauna, and the conservation of energy resources through the shift to renewable sources of energy.

What is surprising about this conservationist approach to sustainability is that this treatment nowhere specifically defines its core meaning. Instead, Brown offers at best a wide ranging (but not exhaustive) enumeration of the constituents of societal or global sustainability. Moreover, as Paehlke notes, 199 Brown's vision of a future sustainable world or society is underpinned by a commitment to slowed, but continuing, economic growth. In sharing this vision with Brown, two other sustainable future advocates, Robert Hamrin, 200 and Dennis Pirages, 201 make clear that their position amounts to a commitment to sustainable growth. For example, Hamrin explicitly notes: "The concept of sustainable growth encompasses the necessity of continued economic growth to meet basic human needs around the globe while also underscoring that the growth be of such a nature that it can be sustained indefinitely by respecting nature's boundary conditions."202 Likewise, in calling for the social design of

199 Paehlke, Robert (1989). Environmentalism and the Future of Progressive Politics, Yale University Press, New Haven.

200 Hamrin, Robert (1983). A Renewable Resource Economy, Praeger Publishing, New York.

201 Pirages, Dennis (1977). "Introduction: A Social Design for Sustainable Growth", in Pirages, D. (ed.), The Sustainable Society, Praeger Publishers, New York, pp. 1-13.

202 Hamrin (1983), op. cit., p. 7. 
sustainable futures on a societal and worldwide scale, Pirages lays out an agenda for sustainable growth defined in terms of "economic growth that can be supported by physical and social environments for the foreseeable future."203

As Samir Amin, ${ }^{204}$ one of the most renowned dependency theorists of the 1960s observed some years ago, the quarrel over the difference between growth and development is no mere semantic disagreement. For Amin and other dependency theorists, growth is not development, and this distinction becomes theoretically and strategically important in peripheral countries where economic growth can mask the absence of true economic development which has been blocked by relations of dependency with core or metropolitan nations of the North. More recently, Daly and Cobb 205 have recontextualized this point within the sustainability debate by defining growth as "quantitative expansion in the scope of the physical dimensions of the economic system," while defining "development" as qualitative change of a physical nongrowing economic system in dynamic equilibrium with the environment. ${ }^{206}$ As they argue, by this definition, the earth is not growing but developing. Any physical subsystem of a

203 Pirages (1977). op. cit., p. 10.

204 Amin, Samir (1976). Unequal Development, Monthly Press, New York.

205 Daly, Herman and John Cobb (1989). For the Common Good: Redirecting the Economy Toward Community, the Environment, and a Sustainable Future, Beacon Press, Boston.

206 Ibid., p. 71. 
finite and nongrowing earth must itself also eventually become nongrowing. Therefore, growth will become unsustainable eventually and the term "sustainable growth" would then be selfcontradictory. But SD, as examined in previous chapters, does not become self contradictory. 207

Part of Daly and Cobb's argument against versions of sustainable growth is grounded in their effort to find an alternative to gross national product (GNP) and net national product (NNP) as a measure of sustainability and in their defense of "strong sustainability" over "weak sustainability" as the core element of SD. Although the elaboration of the former gets into some complicated and subtle economic argumentation which will not be addressed here, the latter distinction carries our analysis of the key concept of sustainability another step further. As against the assumptions of Julian Simon 208 and the late Herman Kahn that postulate the infinite replaceability of finite natural resources by humanly created substitutes, Daly and Cobb press their defense of strong sustainability by arguing that the latter requires "maintaining both humanly created and natural resource capital intact separately, on the assumption that they are complements rather than substitutes in most production functions."209 The

207 Ibid., pp. 71-72.

208 Simon, Julian (1981). The Ultimate Resource, Princeton University Press, Princeton.

209 Daly and Cobb (1989). op. cit., p. 72. 
implications of this argument have been echoed by Amory Lovins 210 in his advocacy of soft energy paths which draw on renewable energy income, instead of hard technology paths which exact a heavy price in terms of scarce human capital.

Within the international development literature, clarification of the SD concept has been advanced most in the work of Michael Redclift. 211 Working from the proposition that SD socially can be discerned in part by the dynamics of ecosystems, Redclift shows how complex ecosystems, like the tropical rainforests, achieve eco-sustainability or homeostatic balance -- what natural ecologists call "climax systems" of high diversity, large biomass, and high stability -- through protection from rapid change and "through shifts of energy flows away from production and towards the maintenance of the systems itself." 212 By contrast, he notes, human settlements typically seek to stall such ecosystems in early stages of ecological succession, where the yield of products is high, but where the stabilizing elements of organic matter and biomass fail to accumulate. High production within these ecosystems, then, comes "at the cost of confounding nature's strategy of maximum protection or adaptation."213

210 Lovins, Amory (1977). Soft Energy Paths: Toward a Durable Peace, Balligner Publishing Co., New York.

${ }^{211}$ Redclift, Michael (1984). Development and the Environmental Crisis: Red or Green, Methuen, London.

212 Ibid., p. 18.

213 Ibid. 
This model of ecological sustainability could be adopted to SD. Of course, natural ecosystems are not equivalent to social systems. Nor are the two ultimately separable. Because the relationship between human settlements and nature is one of identity and difference, human beings in communities live in nature, not with or against nature. Simultaneously, human beings in their non-identity with nature have the capacity of reason to shape their environment and to develop tools to alter or to adapt to their changing environment. Moreover, larger social relations and human groupings (organizations, cities, governments, economies) in their social and historical configurations can strongly influence the compatibility and convergence between natural and social systems.

These philosophical points can be made more concrete by considering other arguments put forth by Redclift. A concept of SD grounded on the sustainability of natural ecosystems, as Redclift suggests, implies a subtle appreciation of the relationship between the carrying capacity of the ecosystem and human population growth. "The concept of sustainability makes little sense," he says, "unless we also consider the impact of population growth on the physical resource base." 214 Carrying capacity is a term engendering much controversy. Daly and Cobb note that some question its appropriateness to human beings. As they acknowledge, the carrying capacity of the environment for 
animals can be calculated basically in terms of population. Per capita resource consumption for animals is both constant over time, but animals do not experience economic development. And it is constant across individual members of the species, since animals do not have rich and poor social classes. ${ }^{215}$ Moreover, technology for animal species "is a genetic constant, while for humans it is a cultural variable." 216

Ecological scarcity may overwhelms the ability of human ingenuity and industry to expand the capacity of the ecosystem to carry ever larger populations of human beings at a decent quality of life. Nevertheless, the problem of overpopulation for the world today in terms of sustainability, as Redclift argues, "is not so much the net increase in population at the global level, but the rate of change in population in the most critical regions."217 Clearly, crucial to ecological sustainability in those areas of the world experiencing the highest rates of population growth are policies fostering improved environmental security-i.e.. practices that preserve indigenous natural resources and prevent environmental degradation. 218

Further, Redclift makes evident, the difficulties of those countries of the South in achieving environmental security and

215 Daly and Cobb (1989). op. cit., p. 136.

216 Ibid.

217 Redclift (1984),, op. cit., p. 133.

218 Ibid., p. 32 
promoting SD programs originate for the most part in models of industrial and agricultural modernization and programs like the "Green Revolution" imported from the North and perpetuated by the finite nature of the energy subsidy provided by depletable oil and natural gas supplies for our wasteful and environmentally destructive forms of modern industrial and agricultural production. More generally, the continuing impact of relations of domination and subordination within an unfolding global political economy poses some of the most daunting problems for moving towards global sustainability, as previously discussed. 


\section{CHAPTER 7. CONCLUSION}

The relationship between the environment and development is complex. In examining the concept of $\mathrm{SD}$ it was suggested that the term could express more than a pious hope, but rather less than a rigorous analytical framework. SD is a concept which draws on two opposed traditions: one concerned with the limits which nature presents to human beings, the other with the potential for human material development which is locked up in nature. Unraveling and deconstructing these concepts has been the primary focus of this thesis. $\mathrm{SD}$, if it is not to be devoid of analytical content, means more than seeking compromise between the natural environment and the pursuit of economic growth. It should mean a definition of development which recognizes the limits of sustainability from the Northern perspective.

It was suggested that the problem in achieving SD was related to the overriding structures of the international economic system, which arose out of the exploitation of environmental resources, and which frequently operate as constraints on the achievement of long-term sustainable practices.

The first inconsistency that lies dormant within SD is: if we cannot rely upon market forces to sustain our environment, we need to place greater reliance on international agreement and planning, without which individual, personal or national, interests will dictate the course of the development process. 219 In

219 See Marien, Michael (1992). "Environmental Problems and Sustainable Futures," Futures October 1992, pp. 731-757. 
discussing environmental management it was argued that most planned, environmental interventions are quite unlike this. Most interventions in the development process on behalf of the environment are motivated by a desire to minimize the "externality" effects of development, rather than to provide lessons in how development can refocus on sustainability. Where environmental considerations clash with strategic, political or national interests, they are unceremoniously forgotten.

Development policy and practice have environmental effects that are indirect and consequently ignored. The debt crisis in Latin America and Africa is a vivid illustration of a problem with serious environmental implications and causes which are routinely considered in exclusively economic, even financial terms.

A second inconsistency concerns the relationship between the political struggles over the environment in developed and developing countries. In seeking sustainability in the North we are seeking to affirm a cluster of related values, concerning the way in which we want our environment to be preserved. We seek, with millions of other people in the developed world, to protect and conserve rural space, to recognize aesthetic values in the countryside, to provide better access to this space and to ensure the biological survival of threatened species. Environmental objectives in the South are rather different. The 
survival of the species is equally important, although possibly for more crudely economic reasons. Otherwise the environment is contested for different reasons. The environment, especially the rural environment, is a contested domain in the South because it is the sphere in which value is created through the application of human labor to nature. If people are to increase their share of material rewards in developing countries, it follows that they must extend their control over the environment, or over the way in which technology transforms the environment.

At this point it is important to remember that the environment has an international character. As Trainer has observed, the material standards of life in the developed countries are intimately linked with the way resources and human labor are exploited in the South.220 It is not left to people in the South to decide how to use their resources. A reduction in the amount consumption, for example, in the industrialized countries can be hailed as a step on the way to more ecological solutions. 221 Whether or not development is necessarily unsustainable as argued by UNEP, it is clearly unsustainable on current models for many of those livelihoods are made in the South, and for reasons that lie outside their control.

This thesis has discussed numerous aspects of development which present barriers to sustainability. It has been argued that

220 Trainer, F.E. (1986). Abandon Affluence!, Zed Books, London, p. 12.

221 Ekins, Paul ed. (1986). The Living Economy, Routledge, New York, intro. 
scientific knowledge is developed in ways that make it difficult to assimilate and utilize the experience of the poor people who depend upon the environment for their survival. The attachment to technological solutions is explicit in terms of the failure to derive relevant knowledge from relevant practice and to exercise the political will necessary to generate global recovery. Anticipatory environmental planning and regulatory practice have a role to play in ameliorating the negative effects of development, but they cannot hope to overcome the barriers to sustainability contained in current development practice. Unless we are prepared to reexamine Western assumptions and practices concerning both development and the environment, and give political effect to the conclusions reached, the reality of unsustainable development will remain, and the risk of ecological destruction will increase. 


\section{BIBLIOGRAPHY}

Acre, A. and Marsden, T.K. (1993). "The Social Construction of Food: A New Research Agenda," Economic Geography, vol. 69, no. 3, pp. 293-311.

Adams, William (1991). Green Development: Environment and Sustainability in the Third World, Routledge, New York

Amin, Samir (1976). Unequal Development, Monthly Press, New York.

Anderson, D.M. and Grove, R.H. (eds.) (1987) Conservation in Africa: People, Policies and Practice, Cambridge University Press, Cambridge.

Ashby, J.A., Quiros, C.A. and Rivera, Y.M. (1987). Farmer Participation in On-Farm Trials, Overseas Development Institute, London

Barbier, Edward (1987). "The Concept of Sustainable Economic Development," Environmental Conservation, vol. 14, no. 2, pp. 101-110.

Barbier, Edward (1989). "Sustainable Agriculture on Marginal Land: A Policy Framework," Environment, vol. 31, no. 9, pp. 13-17, 36-40.

Barbier, Edward (1990). Malawi--Land Degradation in Agriculture Environment, International Institute for Environment and Development, London

Barnet, Richard and Ronald Müller (1974). Global Reach: The Power of the Multinational Corporation, Simon \& Schuster, New York.

Bebbingtion, A. (1991). Farmer organizations in Ecuador: Contributions to Farmer First Research and Development, Sustainable Agriculture Programme Gatekeeper Series no. 26, International Institute for Environment and Development, London.

Birnie, Patricia (1992). "International Environmental Law: Its Adequacy for Present and Future Needs, " in Hurrell, Andrew and Kingsbury, Benedict, eds (1992). The International Politics of the environment: actors, interests, and institutions, Oxford University Press, New York

Broad, Robin and Cavanagh, John (1993). "Beyond the Myths of Rio," World Policy Journal, vol. 10, no. 1, pp. 65-73.

Brown, Becky, Hanson, M., Liverman, D. and Merideth, R. (1987). "Global Sustainability: Toward Definition," Environmental Management, vol. 11, no. 6. p. 714 .

Brown, Lester (1981). Building the Sustainable Society, W.W. Norton and Company, NY. 
Bunch, Robert (1990), Low Input Soil Restoration in Honduras, Agriculture Program Gatekeeper Series no. 23, International Institute for Environment and Development, London

Burkey, Stan (1993). People First: A Guide to Self-reliant, Participatory Rural Development, Zed Books, New Jersey

Caldwell, Lynton (1984). "Political Aspects of Ecologically Sustainable Development, Environmental Conservation, Vol. 11, No. 4, pp. 299-308.

Carriere, Jean (1991). "The crisis in Costa Rica: an Ecological Perspective," in Goodman, David and Redclift, Michael, eds., Environment and Development in Latin America: the Politics of Sustainability, Manchester University Press, Manchester, England

Cernea, Michael (1987). "Farmer Organizations and Institution Building for Sustainable Development," Regional Development Dialogue, pp. 1-19. (Published by the United Nations Center for Regional Development, New York)

Chambers, Robert (1983). Rural Development: Putting the Last First, Longman, London

Chambers, Robert (1986). Sustainable Livelihoods: An Opportunity for the World Commission on Environment and Development, Oxford University Press, New York

Chambers, Robert, Pacey, A. and Thrupp, L. (1989). Farm First: Farmer Innovation and Agricultural Research, Intermediate Technology Publications, London

Cheru, Fantu (1989). The Silent Revolution in Africa: Debt, Development, and Democracy, Zed, London

Choucri, Nazli (1991). "The Global Environment and Multinational Corporations," Technology Review, April, vol. 23, no. 3, pp. 24-40.

Coll, Steve (1992). "A Plan to Save the Globe Dies in a Village," Washington Post, May 24, A1.

Commoner, Barry (1977). The Poverty of Power: Energy and the Economic Crisis, Bantam Books, New York,

Conway, Gordon and Barbier, Edward (1990). After the Green Revolution, Earthscan, New York, pp. 20.

Conway, Gordon and Pretty, J. N. (1991). Unwelcome Harvest: Agriculture and Pollution, Earthscan, New York

Coote, Belinda (1992). The Trade Trap: Poverty and the Global Commodity Markets, Oxfam, Oxford 
Corbridge, S.E. (1990). Capitalist World Development: a Critique of Radical Development Geography, Macmillan, London

Cox, G.W., and Atkins, M. D. (1979). Agricultural ecology: An Analysis of World Food Production Systems, W.H. Freeman, San Francisco

Daly, Herman and John Cobb (1989). For the Common Good: Redirecting the Economy Toward Community, the Environment, and a Sustainable Future, Beacon Press, Boston.

Dandler, J. and Sage, C. (1985). "What is Happening to Andean Potatoes? A View from the Grassroots," World Development, vol. 13, no. 3 pp. 364-371.

Dasmann, R.F. (1985). Achieving the Sustainable use of Species and Ecosystems, Wiley, London

Dover, Michael and Talbot, Lee (1987). To Feed the Earth: Agro-ecology for Sustainable Development, World Resources Institute, Washington, DC,

Doyle, J. (1986). Altered Harvest: Agriculture, Genetics, and the Fate of the World's Food Supply, Penguin Books, New York,

Durning, Alan (1989). "Action at the Grassroots: Fighting Poverty and Environmental Decline." Worldwatch Paper 88, Worldwatch Institute, Washington, DC.

Ekins, Paul (1992). A New World Order: Grassroots Movements for Global Change, Routledge, New York

Ekins, Paul ed. (1986). The Living Economy, Routledge, New York

Farvar, M.T. and Glaeser, B. (1979). Politics of Ecodevelopment, Earthscan, New York

Food and Agriculture Organization (1984). FAO fertilizer yearbook, FAO of the United Nations, New York

Francis, C.A. (1989). Internal Resources for Sustainable Agriculture, Sustainable Agriculture Programme Gatekeeper Series no. 8, International Institute for Environment and Development, London.

French, Hilary (1992). "After the Earth Summit: The Future of Environmental Governance," Worldwatch Paper 107, Worldwatch, Washington, p. 28

Frobel, F., J. Heinrichs, and O. Kreye (1985). "The Global Crisis and Developing Countries", pp. 111-24 in H. Addo et al. Development as Social Transformation: Reflections on the Global Problematique, Hodder and Stoughton, New York 
George, Susan (1985). The Debt Crisis, The Other Economic Summit, London

Ghai, Dharam and Vivian, Jessica (1993). Grassroots Environmental Action: People's Participation in Sustainable Development, Routledge, New York

Ghosh, P.K. ed. (1984). Third World Development: A Basic Needs Approach, Greenwood Press, Westport, Conn.

"Global Management," (1992). Ecologist, vol. 24, no. 4, pp. 180-2.

Godfrey, M, (1986) in T. Rose (ed.) Crisis and Recovery in Sub-Saharan Africa, OECD, Paris

Goodman, David and Redclift, Michael (1992). Refashioning Nature, Food, Ecology, and Culture, Routledge, New York

Goulet, Dennis (1971). The Cruel Choice: A New Concept in the Theory of Development, Atheneum, New York

Haas, Peter (1990). Saving the Mediterranean: The Politics of International Environmental Cooperation, Columbia University Press, New York

Hamrin, Robert (1983). A Renewable Resource Economy, Praeger Publishing, New York.

Hardin, Gareth, and J. Baden (1977). Managing the Commons, W.H. Freeman, San Francisco: CA

Harrell-Bond, B. (1985). "Humanitarianism in a Straightjacket", African Affairs, vol. 84, no. 2, pp. 3-14.

Hayter, T. and C. Watson (1989). Aid: Rhetoric and Reality, Pluto, London.

Hinrichsen, Don (1991). review of Saving the Mediterranean: The Politics of International Environmental Cooperation, by Peter Haas, International Environmental Affairs, vol. 3, no. 3, p. 235.

Holmberg, Johan, Bass, Stephen and Timberlake, Lloyd (1991). Defending the Future - A Guide to Sustainable Development, Earthscan, New York

Huang, H.T. and Pei Yang (1987). "Ancient Culture of Citrus Ant as a Biological Agent," BioScience, vol. 37, pp. 665-71.

ILO, Employment, Growth and Basic Needs, International Labor Organization, Geneva.

IUCN (1990). World Conservation Strategy: Living Resource Conservation for Sustainable Development, Gland, Switzerland: International Union for Conservation of Nature and Natural Resources, United Nations Environment Program and World Wildlife Fund). 
Jacobs, P. and Munroe, D. ,eds., (1987). Conservation with Equity: Strategies for Sustainable Development, proceedings of the Conference on Conservation and Development: Implementing the World Conservation Strategy, Ottawa, Canada, May 31-June 5, 1986, IUCN, Gland, Switzerland.

Johnston, B.F. and W.C. Clark (1982). Redesigning Rural Development: A Strategic Perspective, Johns Hopkins University Press, Baltimore

Kenmore, P., Litsinger, J.A., Bandong, J.P., Santiago, A.C. and Salac, M.M. (1987). "Philippine rice farmers and insecticides: thirty years of growing dependency and new options for change," in Tait, E.J. and Napometh, B. (eds.) Management of Pests and Pesticides: farmers' perceptions and practices, Westview Press, New York,

Kloppenburg, J.R. (1988). First the Seed: The Political Economy of Plant Biotechnology 1492-2000, Cambridge University Press, New York

Korten, David (1991). "Sustainable Development," World Policy Journal, vol. 9, no. 1, pp. 157-189.

Lappe F.M., Collins, Joseph, and Kinley, David (1981), Aid As Obstacle:

Twenty Questions about our Foreign Aid and the Hungry. Grove Press, San Francisco

Lappe, F.M. and Schurman, Rachel (1990) Taking Population Seriously, Grove Press, San Francisco

Lappe, F.M., Schurman, Rachel, and Danaher, Kevin (1987). Betraying the National Interest, Grove Press, San Francisco

Lele, Sharachchandra (1991). "Sustainable Development: A Critical Review," World Development, vol. 19, no. 6, pp. 607-621.

Lewis, Stephen, Jr. (1986) "Africa's Trade and the World Economy," in Robert Berg, and J. Seymour Whitaker (eds.) (1986). Strategies for African Development, University of California Press, Berkeley

Lipton, Michael (1977). Why Poor People Stay Poor, Temple Smith, London.

Lipton, Michael and Longhurst, R. (1989). New Seeds and Poor People, Unwin Hyman, New York

List, Franklin, "Conventional Development Strategies and Basic Needs Fulfillment," reprinted as Reading 5 in Todaro, Michael ed. (1983).The Struggle for Economic Development, Longman, New York

Lohman, Larry (1991). "Who Defends Biological Diversity?" Ecologist, vol. 21 , no. 1 , pp. 5-13 
Lopez Cordovez, L. (1982). "Trends and Recent Changes in the Latin American Food and Agriculture Situation," CEPAL Review, vol 16, United Nations Economic Commission for Latin America.

Lovins, Amory (1977). Soft Energy Paths: Toward a Durable Peace, Balligner Publishing Co., New York

Maathai, Wangari (1986). The Green Belt Movement: Building Block for Sustainable Development, Overseas Development Institute, London,

Marien, Michael (1992). "Environmental Problems and Sustainable Futures," Futures October 1992, pp. 731-757.

Maslow, A.H. (1970). Motivation and Personality, 2nd edn. Harper and Row, New York

McNeely, Jeffrey and Pitt, David eds. (1985). Culture and Conservation: The Human Dimension in Environmental Planing, Croom Helm, London.

Merchant, Carolyn (1992). Radical Ecology: The Search for a Livable World, Routledge, New York,

Momsen, J.H. (1991). Women and Development in the Third World, Routledge, London

Morris, J. (1990). Extension Alternatives in Tropical Africa, Overseas Development Institute, London

Morrisette, Peter and Plantinga, Andrew (1991). "Global Warming: A Policy Review," Policy Studies Journal, vol. 19, no. 2, pp. 163-172.

Murdoch, William (1980). The Poverty of Nations, Johns Hopkins University Press, Baltimore

National Research Council (1984). Pesticide Resistance Strategies and Tactics for Management, National Academy Press, Washington, DC

Nations, B. and L. Korner (1983). "Cattle Eat the Forest," Environment, vol. 25 , no. 2 , pp. $32-41$.

Nebel, B. J. (1991), Environmental Science, Prentice-Hall, Englewood Cliffs, N.J.,

Norgaard, Richard (1984). "Coevolutionary Agricultural Development," Economic Development and Cultural Change, vol. 32, no. 3, pp. 343-366.

Norgaard, Richard (1989). "Sustainable Development: A Coevolutionary View," Futures, vol. 20, no. 6, pp. 606-620.

Nowicki , P. (1985). "Cultural Ecology and Management of Natural Resources or Knowing When not to Meddle," in McNeely, J. and Pitt, D., 
Culture and Conservation: The Human Dimension in Environmental Planing

Nyerere, Julius (1985). "Africa and the Debt Crisis", African Affairs, vol. 84, no. 2 , pp. $489-98$.

O'Brien, Paul (1986). “ The Debt Cannot be Paid," Bulletin of Latin American Research, vol. 5, no. 1, pp. 12-36.

O'Riordan, Timothy. (1985). "Future Directions in Environmental Policy," Journal of Environment and Planning, vol. 17 pp. 1431-1446.

Onimode, Bade (ed.) The IMF, The World Bank and The African Debt: The Social \& Political Impact, Zed Books, London.

OTA (Office of Technology Assessment) (1988). Enhancing Agriculture in Africa: A Role for US Development Assistance, US Government Printing Office, Washington, DC

Ovington, J. and Fox, A. (1980). Wilderness - A Natural Asset, Cambridge University Press, Cambridge

Oxfam America (1986) "Third World Debt: Payable in Hunger", Facts for Action 16.

Paehlke, Robert (1989). Environmentalism and the Future of Progressive Politics, Yale University Press, New Haven.

Patten, Christopher (1990). "Common Future- Common Challenge: Aid Policy and the Environment," in D.R. Angell, J.D. Comer, and M.L. Wilkinson (eds.) Sustaining Earth: Response to the Environmental Threat, St. Martin's Press, New York

Payer, Cheryl (1974). The Debt Trap: The IMF and the Third World, Monthly Review Press, New York.

Payer, Cheryl (1989). "Causes of the Debt Crisis," in Onimode, Bade (ed.) The $I M F$, The World Bank and The African Debt: The Social \& Political Impact, Zed Books, London

Pearce, David, Markandya, Anil and Barbier, Edward (1989). Blueprint for a Green Economy, Earthscan, New York

Peet, John (1992). Energy and the Ecological Economics of Sustainability, Island Press, Washington, DC

Pirages, Dennis (1977). "Introduction: A Social Design for Sustainable Growth", in Pirages, D. (ed.), The Sustainable Society, Praeger Publishers, New York. 
Raeth, Paul (1993). Agricultural Policy and Sustainability: Case Studies From India, Chile, the Philippines, and the United States, World Resources Institute, Washington, DC,

Redclift, Michael (1984). Development and the Environmental Crisis: Red or Green, Methuen, London.

Redclift, Michael (1987). Sustainable Development: Exploring the Contradictions, Methuen, New York.

Reid, Walter (1989). "Sustainable Development: Lessons from Success," Environment, vol. 31, no. 9, pp. 27-35.

Repetto, Robert (1990). "Environmental Productivity," Challenge, vol. 33, no. 5, Sept-Oct , pp. 33-48.

Rich, Bruce (1985). "Multilateral Development Banks-Their Role in Destroying the Global Environment," The Ecologist, vol. 15, no. 2, p. 56.

Rich, Bruce (1994). Mortgaging the Earth: The World Bank, Environmental Impoverishment, and the Crisis of Development, Beacon Press, Boston

Ritchie, Mark, (1994) "GATT Facts: Africa Loses Under GATT", Institute for Agriculture and Trade Policy, March 1994.

Rose, S., R. Lewontin, and L. Kamin (1984). Not in Our Genes: Biology, Ideology and Human Nature, Penguin, New York

Ruchelshaus, William (1989). "Toward a Sustainable World," Scientific American, vol. 261, no. 3, Sept. pp. 166-174.

Samatar, Abdi (1993). "Structural Adjustment as Development Strategy? Bananas, Boom, and Poverty in Somalia," Economic Geography, vol. 69, no. 1 , pp. 25-43.

Schmidheiny, Stephan (1992). Changing Course: A Global Perspective on Development and the Environment, MIT Press, Cambridge,

Sebstad, Jennifer (1990). Women and Self-reliance in India: The SEWA Story, Zed, London.

Sen, Amartya (1983). "Development: Which way now?" The Economic Journal vol. 93 December, pp. 754-757.

Shiva, Vandana (1991). The Violence of the Green Revolution. Zed Books, London

Simon, J. and Kahn, J. (1984). The Resourceful Earth, Blackwell, New York.

Simon, Julian (1981). The Ultimate Resource, Princeton University Press, Princeton. 
Slater, D. (1985). New Social Movements and the State in Latin America, Blackwell, London.

Smith, N. (1984) Uneven Development, Blackwell, London

Stewart, Frances (1985). Planning to Meet Basic Needs, Macmillan, New York

Tangwisuttijit, Nantiya (1991). "Arguments that Hold Water," Nation, October 5, pp. C1-C3.

The Economist, "A Survey of Third World Finance: New Ways to Grow," Sept 25, 1993, pp. Survey 1-43.

The Economist, "What's Wrong with Foreign Aid?" May 7, 1994, pp. 19-22.

Timberlake, Lloyd (1985). Africa in Crisis: The Causes, The Cures of Environmental Bankruptcy, Earthscan, New York

Timberlake, Lloyd (1987). Only One Earth: Living for the Future, BBC and Earthscan, London

Tisdell, Clem (1988). "Sustainable Development: Differing Perspectives of Ecologists and Economists, and Relevance to LDCs," World Development, vol. 16, no. 3, pp. 377-384.

Tolba, Mostafa (1987). Sustainable Development: Constraints and Opportunities, Butterworths, London

Trainer, F.E. (1986). Abandon Affluence!, Zed Books, London

Turner, B.L.; Clark, W.C., Kates, R.B., Richards, J.F., Mathews, J.T., and Meyer, W.B. (eds) (1990), The Earth as Transformed by Human Action, Cambridge University Press, Cambridge.

UNDP (1994). Human Development Report 1994 Oxford University Press, New York

UNEP (1984). General Assessment of Progress in the Implementation of the Plan of Action to Combat Desertification, UNEP, New York

UNICEF (1993). The Progress of Nations, UNICEF, New York

Uphoff, Norman (1990). "Paraprojects as New Modes of International Development Assistance," World Development, vol. 18, no. 11, pp. 1401-11.

Whose Common Future? Reclaiming the Commons (1993). Written by The Ecologist, Earthscan, London 
Wolf, Edward (1986). Beyond the Green Revolution: New Approaches for Third World agriculture, Worldwatch Paper, no. 73, Worldwatch Institute, Washington, DC.

World Bank (1974). Population Policies and Economic Development, Johns Hopkins University Press, Baltimore

World Bank (1984). World Development Report 1984,, Oxford University Press, New York.

World Bank (1992). Effective Implementation: Key to Development Impact World Bank (1992). The Development Report, World Bank, Washington, D.C.

World Bank (1993). Social Indicators of Development 1993, The Johns Hopkins Press, Baltimore MA.

World Commission on Environment and Development (1987). Our Common Future, Oxford University Press, New York.

World Resources Institute, World Resources 1990-1991, Oxford University Press, New York

Yapa, Lakshman (1993). "What are Improved Seeds? An Epistemology of the Green Revolution," Economic Geography, vol. 69, no. 3, pp. 254-273. 